Georgia State University

ScholarWorks @ Georgia State University

\title{
Reexamining The Determinants Of Fiscal Decentralization: What Is The Role Of Geography?
}

Gustavo J. Canavire-Bacarreza

Georgia State University, gcanavir@eafit.edu.co

Jorge Martinez-Vazquez

Georgia State University, jorgemartinez@gsu.edu

Follow this and additional works at: https://scholarworks.gsu.edu/icepp

Part of the Economics Commons

\section{Recommended Citation}

Canavire-Bacarreza, Gustavo J. and Martinez-Vazquez, Jorge, "Reexamining The Determinants Of Fiscal Decentralization: What Is The Role Of Geography?" (2012). ICEPP Working Papers. 62.

https://scholarworks.gsu.edu/icepp/62

This Working Paper is brought to you for free and open access by the International Center for Public Policy at ScholarWorks @ Georgia State University. It has been accepted for inclusion in ICEPP Working Papers by an authorized administrator of ScholarWorks @ Georgia State University. For more information, please contact scholarworks@gsu.edu. 
International Center for Public Policy

Working Paper 12-11

February 2012

Reexamining the Determinants of Fiscal Decentralization: What Is The Role of Geography?

\section{Gustavo Canavire-Bacarreza} Jorge Martinez-Vazquez 



\author{
International Center for Public Policy \\ Working Paper 12-11
}

\title{
Reexamining the Determinants of Fiscal Decentralization: What Is The Role of Geography?
}

\author{
Gustavo Canavire-Bacarreza \\ Jorge Martinez-Vazquez
}

February 2012

International Center for Public Policy

Andrew Young School of Policy Studies

Georgia State University

Atlanta, Georgia 30303

United States of America

Phone: (404) 651-1144

Fax: (404) 651-4449

Email: hseraphin@gsu.edu

Internet: http://aysps.gsu.edu/isp/index.html

Copyright 2006, the Andrew Young School of Policy Studies, Georgia State University. No part of the material protected by this copyright notice may be reproduced or utilized in any form or by any means without prior written permission from the copyright owner. 


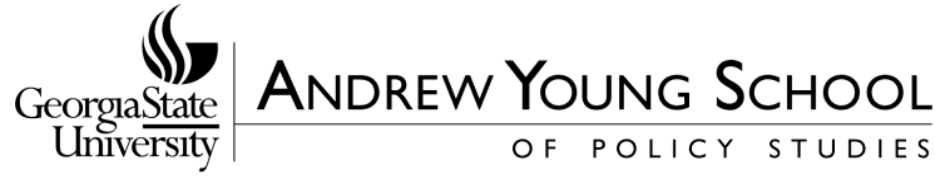

\section{International Center for Public Policy Andrew Young School of Policy Studies}

The Andrew Young School of Policy Studies was established at Georgia State University with the objective of promoting excellence in the design, implementation, and evaluation of public policy. In addition to two academic departments (economics and public administration), the Andrew Young School houses seven leading research centers and policy programs, including the International Center for Public Policy.

The mission of the International Center for Public Policy is to provide academic and professional training, applied research, and technical assistance in support of sound public policy and sustainable economic growth in developing and transitional economies.

The International Center for Public Policy at the Andrew Young School of Policy Studies is recognized worldwide for its efforts in support of economic and public policy reforms through technical assistance and training around the world. This reputation has been built serving a diverse client base, including the World Bank, the U.S. Agency for International Development (USAID), the United Nations Development Programme (UNDP), finance ministries, government organizations, legislative bodies and private sector institutions.

The success of the International Center for Public Policy reflects the breadth and depth of the in-house technical expertise that the International Center for Public Policy can draw upon. The Andrew Young School's faculty are leading experts in economics and public policy and have authored books, published in major academic and technical journals, and have extensive experience in designing and implementing technical assistance and training programs. Andrew Young School faculty have been active in policy reform in over 40 countries around the world. Our technical assistance strategy is not to merely provide technical prescriptions for policy reform, but to engage in a collaborative effort with the host government and donor agency to identify and analyze the issues at hand, arrive at policy solutions and implement reforms.

The International Center for Public Policy specializes in four broad policy areas:

- Fiscal policy, including tax reforms, public expenditure reviews, tax administration reform

- Fiscal decentralization, including fiscal decentralization reforms, design of intergovernmental transfer systems, urban government finance

- Budgeting and fiscal management, including local government budgeting, performancebased budgeting, capital budgeting, multi-year budgeting

- Economic analysis and revenue forecasting, including micro-simulation, time series forecasting,

For more information about our technical assistance activities and training programs, please visit our website at http://aysps.gsu.edu/isp/index.html or contact us by email at hseraphin@gsu.edu. 


\title{
Reexamining The Determinants Of Fiscal Decentralization: What Is The Role of Geography?"
}

\author{
Gustavo Canavire-Bacarreza and Jorge Martinez-Vazquez \\ International Center for Public Policy \\ Georgia State University
}

\begin{abstract}
This paper contributes to the existing literature on the determinants of fiscal decentralization by motivating theoretically and exploring in depth the empirical relevance that geography has as determinant of fiscal decentralization. The relationship between decentralization and geography is based on the logic that more geographically diverse countries show greater heterogeneity among their citizens, including their preferences and needs for public goods and services provision. Communications and physical distance are also a very important issue and play a key role on the effect of geography over time. The theoretical model builds on the work by Arzaghi and Henderson (2002) and Panizza (1999). For the empirical estimation we use a panel data set for approximately 91 countries for the period 1960-2005. Physical geography is measured along several dimensions including elevation, land area, and climate. We construct a geographical fragmentation index and test its effect on fiscal decentralization. In addition, we interact the geographical fragmentation index with time variant infrastructure variables, in order to test the effect that infrastructure and communications have on the relationship between geography and fiscal decentralization. For robustness, we construct Gini coefficients for in-country elevation and climate. We find a positive and strong correlation between geographical factors and fiscal decentralization. We also find that while the development of infrastructure (in transportation, communications, etc.) tends to reduce the effect of geography on decentralization, this effect is rather small and mostly statistically insignificant, meaning that the impact of geography survives over time. The additional value added of this strategy is that geography and its interaction with infrastructure development may be used as an instrument for decentralization in future econometric estimations, where decentralization is used as an explanatory variable but it may be suspected to be endogenous to the economic process being studied (economic growth, political instability, macroeconomic stability, income distribution, etc.)
\end{abstract}

\footnotetext{
* International Center for Public Policy, Andrew Young School of Policy Studies and Department of Economics at Georgia State University. Comments are welcome at jorgemartinez@gsu.edu and gcanavirebacarreza@gsu.edu
} 


\section{Introduction}

For several decades there has been an increasing interest in the vertical organization of government in developed and developing countries. The main question asked is whether it is advantageous to give sub-national governments more authority and autonomy in revenue and expenditure decisions, or whether it is better to make those decisions at the central level of government. Many scholars and policy makers have sought to understand the consequences of fiscal decentralization. ${ }^{2}$ Far less effort, however, has gone into discerning the causes of fiscal decentralization. Variation in the degree to which countries have devolved fiscal resources and expenditure responsibilities to local and regional governments presents researchers with a puzzle. Some authors such as Treisman (2006), Arzaghi and Henderson (2002), Panizza (1999), Oates (1972), among others, have proposed plausible models for the determinants of fiscal decentralization. The origins of fiscal federalism, they argue, are the outcome of a myriad assortment of factors: history, culture, politics, and even physical geography. There is also a long empirical literature examining the determinants of fiscal decentralization across countries and over time such as Bahl and Linn (1992), Wasylenko (1987), Panizza (1999), and Letelier (2005) among others.

Considering the role of geography more specifically as a determinant of decentralization, papers by Panizza (1999) and Arzaghi and Henderson (2005) examine theoretically and empirically the effects of country size on fiscal decentralization, while others such as Letelier (2005) and Treisman (2006) test empirically the same relationship. However, there is no study that has examined in depth the role that geography can play on fiscal decentralization. Currently, we still have limited knowledge on the modeling of geography in the theory of decentralization and what

\footnotetext{
${ }^{2}$ In fact, there is an extensive literature that examines the relationship between fiscal decentralization and its effects on growth, income distribution and poverty, corruption and so on. See, for example, Martinez-Vazquez and McNab, (2001) and the articles in the special issue of Environment and Planning: C (2009) issue 2.
} 
empirical role geography actually plays.

Understanding the determinants of fiscal decentralization has become increasingly important for many areas of economic research. Given the pervasiveness of decentralized institutions and decision making in many areas of economic policy including economic growth, income redistribution, poverty and welfare, anticorruption, and others, it has become a necessity in empirical studies to control for the role and impact of fiscal decentralization on those policy initiatives. A common problem shared by all those empirical studies has been the inability to properly address the potential for endogeneity of decentralization and the dependent variables of interest (e.g., economic growth, etc.). Generally speaking there has been a lack a proper external instrument when assessing the relationship between decentralization and economic outcomes. Often, remedies for the endogenous nature of fiscal decentralization have been sought in the use of new econometric techniques such as difference or system dynamic panel estimation, while there has been very limited use of valid external instruments. Geography has clear exogeneity credentials, since economic outcomes do not cause geography. ${ }^{3}$ However, it needs to be recognized that the use of geography as an instrument for decentralization is limited by the type of estimation approach being used; what makes geography a good external instrument-- that is fixed by nature--, largely rules out its use in certain econometric approaches such as panel estimation using fixed effects. ${ }^{4}$

The main objective of this paper is to motivate theoretically the role of geography, and explore in depth its empirical relevance as a determinant of decentralization. The theoretical model in the paper builds on the work by Arzaghi and Henderson (2002) and Panizza (1999). For the empirical estimation we use a panel data set for approximately 91 countries for the period 1960-

\footnotetext{
${ }^{3}$ Even if the economy may affect the access to markets and urban centers, especially in rich countries, economic outcomes cannot affect directly geographical factors such as elevation or climate among others.

${ }^{4}$ Note that by interacting geography and infrastructure development it is possible to construct a new variable that is time variant but then this new variable cannot be claimed to be truly exogenous.
} 
2005. Physical geography is measured along several dimensions including elevation, land area, and climate.

The relationship between decentralization and geography is based on the logic that more geographically diverse countries tend to show greater heterogeneity among their citizens, including their preferences and needs for public goods and services provision. Communications and physical distance are also important factors and play a key role on the effect of geography over time. As Lora et al. (2003) argue, geography plays a fundamental role on the economic and social development as well as the institutional design of countries; yet, this effect could be enhanced (or diminished) in the presence of better physical infrastructure or communications. Indeed, in this paper we find that there is a strong correlation between geographical factors and fiscal decentralization. We also find that while the development of infrastructure (in transportation, communications, etc.) tends to reduce the effect of geography on decentralization, this effect is rather small and often statistically insignificant, meaning that the raw impact of geography appears to survive over time.

The reminder of the paper is organized as follows. Section 2 briefly reviews the literature on the main determinants of decentralization and describes the main intuition and arguments for the relationship between decentralization and geography. Section 3 develops the theoretical model and discusses the main hypothesis. Section 4 presents the data used and the empirical estimation. Section 5 discusses the results and the robustness of the estimations. Finally, Section 6 concludes.

\section{Literature Review}

The literature on fiscal decentralization is very large and growing at a fast pace. Without trying to be exhaustive our interest in this review is focused on two main issues. First, we examine how the existing theoretical models explaining decentralization (Oates, 1972; Panizza, 1999; and Arzaghi and 
Henderson, 2005) could be reinterpreted in the light of the role that physical geography may play on how decentralized different countries may become. Second, we review to what extent past empirical studies of fiscal decentralization have used variables that could be associated with different aspects of geography, and identify as well what other determinants of fiscal decentralization have been found to be significant.

But before we do this, some general observations about the role of geography in modern economic thought and the 'new economic geography' are relevant to understanding the potential role of geography in decentralization. Historians, such as Jones (1981) and Crosby (1986) in examining the economic success of Europe find geography and climate to be of central importance. Jones (1981) stresses Europe's great advantages in coastal trade, navigable rivers, temperate climate, and suitable disease patterns as fundamental conditions for the European takeoff and eventual domination of the Americas and Africa. Crosby (1986) details the advantages of the temperate zones in climate, disease ecology, and agricultural productivity and its effects on the organization of governments.

In the work on geography by Krugman and Venables (1995), the "new geography" follows the "new trade theory" in showing how increasing returns to scale, agglomeration economies, transport costs, and product differentiation can lead to a highly differentiated spatial organization of economic activity, the creation of stable institutions and governments, even when the underlying physical geography is not fully undifferentiated. These models illustrate the possibility of "selforganizing" spatial patterns of production based on agglomeration effects, rather than on differences in climate, transport costs, ecology, etc.

Our starting point is that highly differentiated physical geography can have large effect on economic and institutional development. For example, a pattern of cities might originally emerge 
because of cost advantages arising from differentiated geography, and therefore the advantages of having a decentralized system would be justified on the arguments of the decentralization theorem (Oates (1972)). However, these cities then continue to thrive as a result of agglomeration economies even when the cost advantages have disappeared. Oates (1972) argues that economic efficiency can be enhanced across population groups with different preferences and needs through decentralization. We borrow this argument to argue that geographical factors can follow this logic as well. Preferences for public goods and services are likely to vary across geographically differentiated regions. If this is so, greater utility will result if different baskets of public goods and services are provided to different, homogeneous sub regions. For example, if education policy is made at the regional rather than the central level, then local residents can set syllabi and levels of education financing in their home regions to best suit their tastes.

In addition, greater efficiency in public service provision can be achieved through the mobility and sorting of the population in decentralized governments (Tiebout, 1956). On the face of it, any decentralized expenditure scheme could also be implemented by a centralized government, so the efficiency argument requires some additional assumption. A common one is that local governments are either more efficient at collecting information about tastes or better able to get local constituents to reveal such information (Tanzi, 2000; Loockwood, 2002 and Besley \& Coate, 2003). Other authors argue that accountability plays a key role since decentralization may be the best way to create incentives for politicians to differentiate adequately between the needs of different groups of their citizens and therefore optimize the provision of public goods (Seabright, 1996). Politicians would be willing to modify their objectives to satisfy preferences of their incumbents at local level, since that would help them in re-elections.

The examination of the determinants of decentralization can be split between theoretical and 
empirical evidence. On the theoretical side, beyond Oates (1972) classical paper presenting the decentralization theorem, important more recent contributions are those by Panizza (1999) and Arzaghi and Henderson (2005). Panizza (1999) bases his analysis on the fact that if the magnitude of welfare gains has any explanatory power, then we would observe a greater role for sub-national government in countries with greater cultural heterogeneity (provided that the variance in tastes is larger between jurisdictions than within them). This prediction is reinforced by, but by no means wholly dependent on, a population with a high degree of mobility. He links the size of the public sector to taxpayers' satisfaction with the type of public goods provided. Thus, a budget-maximizing central government faces a trade-off between its share in the public sector and the total size of the public sector. A gain in the total size of the public sector can result from mobility making the public goods provided closer to the preferences of the individual (in terms of physical and social distance), thus making them demand more of the public good whose type better matches their preferences. Moreover, with an increasing level of democracy, governments are dependent on the residents' satisfaction with public goods. His model suggests that the equilibrium level of decentralization should be positively correlated with the heterogeneity of tastes for public goods among residents with the level of democracy and with country size. In particular, Panizza (1999) argues that the size of a country has a close relation with the level of heterogeneity of preferences and therefore an increase in the size of the country will decrease the the marginal benefits from centralization. It is easy to extend Panizza's argument about country size to other components of geography even though Panizza (1999) did not consider them.

Arzaghi and Henderson (2005) model the creation of sub-national governments (under restricted mobility) as being determined by balancing the fixed costs of sub-national administration with the "spatial decay" of goods provided from the center. For a benevolent government, their model predicts that adoption of decentralized structures is promoted by (1) larger income, (2) larger 
population, (3) higher spatial decay of local public services provided to the hinterland by the central government, (4) higher relative income in the hinterland region, (5) larger population share of the hinterland, and (6) lower fixed costs of government for the hinterland region. For a partially Leviathan government, their model has the same predictions as those above for a benevolent government; in addition, the adoption of decentralized structures is promoted by there being a greater relative degree of local democratic culture when compared to the national level. In other words, sub-national governments are thought to be more responsive to the local constituencies than the central government. Even though Arzaghi and Henderson (2005) do not explicitly model the role of geography again it is quite intuitive that spatial decay in the provision of public goods can be related to intensity of physical geography.

Empirically, the causes of decentralization have received a lot more attention. In some of the earliest work, Pryor (1967), Oates (1972), and Pommerehne (1977) tested some basic hypotheses on the determinants of fiscal decentralization. The factors associated with geography, such as the population size of the country, as a whole appear to be significant and positively related to fiscal decentralization. In a later study, Kee (1977) measures the impact of urbanization and other variables on fiscal decentralization. The urbanization variable, which Kee claims is used as a geographical control, appears to be positively related to fiscal decentralization. In addition, Wasylenko (1987) finds that there are non-linear effects of urbanization on fiscal decentralization.

Ethnic fractionalization, a variable that has been frequently used as a control in empirical studies of decentralization, could also be related to geographical factors, because geographical diversity is likely to lead to ethnic fractionalization and heterogeneous preferences for different population groups. In this line, Panizzas' (1999) empirical results show a positive effect of ethnic fractionalization and country area on fiscal decentralization. More recently, Letelier (2005) and 
Freikman (2005) find a similar result for the ethnic fractionalization variable using broader definitions of fiscal decentralization. Perhaps one of the most important geographical measures that have been used on the analysis of fiscal decentralization is the country size. Treisman (2006) and Martinez-Vazquez and Timofeev (2009) find that fiscal decentralization tends to be greater in territorially larger countries, given the use of other control variables. ${ }^{5}$ As Panizza's (1999) argues larger countries are likely to have greater heterogeneity and dispersion on tastes and therefore greater efficiency gains to realize from decentralization.

On a concluding note, Lora et al. (2003) have pointed out that geographical fragmentation is a concept usually neglected by economists and even by political scientists; but without getting into an analysis of how justified that observation may be, we would argue that many social and economic cleavages have a variety of geographical underpinnings. Culture usually differs widely among inhabitants of different ecozones (reflected either by altitude or climate zone); thus, for example, the contrast between outgoing and vocal lowlanders and timid and taciturn highlanders has become one of the most verified clichés around the world (Gallup and Sachs, 1998). The composition of economic activity can differ widely among ecozones; for example, crops, mineral deposits, or proximity to the ocean are in general different from one zone to the other. ${ }^{6}$ These factors, through different channels such as access to markets, have a direct impact on the value of exploiting or not some resources such as gas or minerals or on land use patterns. In summary, geographical fragmentation is a dimension of social diversity and as such can play a pivotal role in the

\footnotetext{
5 Triesman (2006) argues that although the relationship between country size and fiscal decentralization emerges strongly from the data, we do not have a compelling theory to explain why this should be the case. He points out that most theoretical analysis of this question has been normative and showing that in larger countries greater fiscal decentralization is likely to be more efficient. But since decisions to decentralize result from bargaining between selfinterested central and local politicians (and their constituencies), it is not clear why efficiency argument would tend to win the day.

${ }^{6}$ Mellinger et. al. (2000 and Gallup and Sachs (1998) find compelling evidence that different ecozones lead to different economic structures. For example, the density of economic activity measured as GDP per km2 is high in lower altitude and temperate ecozones and in regions proximate to the sea (within $100 \mathrm{~km}$ of the ocean or a sea-navigable waterway).
} 
organization of politics and the economy. In the following two sections we make the theoretical and empirical arguments for how geographical fragmentation becomes an important determinant of decentralization.

\section{Theoretical Framework}

Our model builds on Arzaghi and Henderson (2002) in combination with some features from Panizza (1999) with the goal of explicitly including geographical fragmentation in the theoretical decentralization framework. Our aim is to add to our understanding why countries may adopt a decentralized versus a centralized system of finance. We assume that people have similar preferences, however they differ in their tastes for public goods; this assumption is plausible if we think that preferences for public goods can differ along the territory. Education is an example of publicly provided services which may exhibit differences on preferences across regions; some regions may prefer schooling to be provided in a different language, or in a bilingual way, while others may prefer keeping a single most common language. As another example, the organization of health services in congested urban areas may not fit the needs of sparsely populated rural areas, calling for differences in the provision of public services in different areas.

For simplification, based on Fujita, Krugman and Venables (1999) and Panizza (1999), we argue that preferences are directly affected through differences in geography (geographical fragmentation), and social-cultural factors (such as ethnic fractionalization). While these two factors are related, they differ in a subtle way; ethnic fractionalization will affect the preferences directly through taste differences, while geographical fragmentation will not only affect tastes but also will affect the provision of public goods because geographical fragmentation works as a spatial decay factor for centrally provided public goods. Thus, geographical differences are expected to have an effect on both preferences and access to public service provision. But, in addition, in line with 
Gallup and Sachs(1998) and Fujita and Mori (2005), we also claim that geographical disparities should bring differences in needs brought about by the environment as well as the economic costs of provision.

Let us assume that the public sector has the main function of providing a fully congestible public good, with per capita consumption of $g$, and that the regions operate under two possible "states," state 1 when the regions operate within a centralized system, and state 2 when the regions operate within a decentralized system. ${ }^{7}$ We also assume that the population for the country is given by the sum of populations of all the different regions $L=\sum_{i=1}^{n} L_{i}$ and that national income is given by $Y$ which is the sum of incomes $y_{i}$ in the regions $Y=\sum_{i=1}^{n} y_{i}$.

As in Arzaghi and Henderson (2002), we assume a representative agent whose preferences are represented by a simple Cobb-Douglas utility function of the type:

$$
u=x^{\alpha} g^{\beta}
$$

where $x$ is the private good and $g$ the public good. We assume that $\alpha+\beta=1$, and that public goods are financed with a proportional tax on income at a rate $t_{i}$. Consequently, $x_{i}=y_{i}\left(1-t_{i}\right)$, and the utility function becomes:

$$
u_{i}=y_{i}^{\alpha}\left(1-t_{i}\right)^{\alpha} g_{i}^{\beta}
$$

Under a centralized system (state 1), the costs of maintaining the government is fixed and set

\footnotetext{
${ }^{7}$ For simplification we abstain from including other factors that typically affect the operation of fiscally decentralized system such as expenditure needs, fiscal capacity or borrowing constraints.
} 
at $F$ and using the price of public goods as a numeraire, then the budget constraint is given by:

$$
Y t=F+\left(\sum_{i=1}^{N} L_{i}\right) g \text { and } Y=\sum_{i=1}^{N} L_{i} y_{i}
$$

This budget constraint can be rewritten as:

$$
t=\frac{(F+g L)}{Y}
$$

Additionally we assume that a dollar spent on the public good will not necessarily provide a dollar of public good services due to the existence of a spatial decay process represented by the component $\delta=\delta(\gamma, \eta)$. That is, we assume that the spatial decay component, $\delta$, is composed of two parts, one that captures straight geographical fragmentation, $\eta$, and the other that captures differences in tastes $\gamma$. The relation between geographical fragmentation and spatial decay should be necessarily positive, as highly fragmented countries will not only have more difficulties in the regular provision of public goods but also will generally have more ethnically or culturally fragmented population. Thus, we would expect a positive relation between geographical fragmentation and spatial decay, $\frac{\partial \delta(\gamma, \eta)}{\partial \eta}>0$. On the preferences side, $\gamma$, a more ethnically fragmented country is assumed to lead to higher spatial decay, as less homogenous body of voters will have a wider spectrum of demands when it comes to desired package of public goods.

Therefore, the utility of the representative individual in state 1 (centralized system) would be given by:

$$
u_{i}=y_{i}^{\alpha}\left(1-\frac{F}{Y}-\frac{g L}{Y}\right)^{\alpha} g^{\beta}[1-\delta(\gamma, \eta)]^{\beta}
$$


Then, we calculate the value of $g$ that maximizes the utilities under a centralized system. The maximization problem results in:

$$
g=\beta\left(\frac{Y-F}{L}\right)
$$

and the utility is:

$$
u_{i}=\alpha^{\alpha} \beta^{\beta} y_{i}\left(1-\frac{F}{y_{i}}\right)\left(\frac{1}{L}\right)^{\beta}[1-\delta(\gamma, \eta)]^{\beta}
$$

From this equation, it is possible to derive the following proposition in relation with geographical complexity.

The utility in a centralized system is decreasing in income per capita $\frac{\partial u_{i}}{\partial y}<0$ the level of taste differentiation $\frac{\partial u_{i}}{\partial \delta}<0$, and the level of geographical fragmentation $\frac{\partial u_{i}}{\partial \eta}<0$ since $\frac{\partial \delta(\gamma, \eta)}{\partial \eta}>0$.

The interpretation is straightforward. Higher geographical complexity is associated with faster spatial decay and therefore lower utility under a centralized system pointing to the conclusion that more geographically fragmented countries will tend to have higher levels of fiscal decentralization. To see this let us next develop the theoretical framework under fiscal decentralization.

Under a decentralized system (state 2) each region operates autonomously and the costs of running a government $\left(F_{i}\right)$ are fixed but potentially different for each region, the levels of public good provided in each region, $g_{i}$, may vary, and no spatial decay component is assumed to be present. Under these conditions the budget constraint is in each region given by: 


$$
t_{i} L_{i} y_{i}=F_{i}+g_{i} L_{i} \text { and the tax rate is given by, } t_{i}=\frac{F_{i}}{L_{i} y_{i}}+\frac{g_{i}}{y_{i}}
$$

Given these conditions, the utility of the representative individual in each region in state 2 will be:

$$
u_{i}=\left(y_{i}-\frac{F_{i}}{L_{i}}-g_{i}\right)^{\alpha} g_{i}^{\beta}
$$

, which when maximized with respect to $g_{i}$ results in $g_{i}=\beta\left(y_{i}-\frac{F_{i}}{L_{i}}\right)$ and

$$
u_{i}=\alpha^{\alpha} \beta^{\beta}\left(y_{i}-\frac{F_{i}}{L_{i}}\right)
$$

We now can examine the decentralization process in a decision framework evaluating the costs and benefits from operating within a centralized versus a decentralized structure. A region will push for decentralization as long as the utility under state 2 (decentralized system) is larger than the utility obtained in state 1 (centralized). In other words, the centralized system will prevail as long as:

$$
1-\frac{F_{i}}{y_{i} L_{i}} \leq\left(1-\frac{F}{Y}\right)\left(\frac{Y}{y_{i} L}\right)^{\beta}[1-\delta(\gamma, \eta)]^{\beta}
$$

A second proposition arises from the above equation:

The higher the level of geographical complexity $\eta$ and ethnic diversity $\gamma$, the higher de relative gain from 
moving to a decentralized system of public good provision. ${ }^{8}$

One final point relates to how infrastructure development may affect the role of geography. As argued by Lora et. al. (2003), the role that geography plays in the economic-social development and the institutional design of countries may be enhanced (or diminished) in the presence of better physical infrastructure or communications. To allow for these effects in our theoretical framework we let the index of geographical fragmentation to depend on the level of infrastructure development, so $\eta=f(p)$, where $p=$ infrastructure and where we assume that $\frac{\partial \delta(\gamma, \eta)}{\partial \eta}>0$ and $\frac{\partial \delta(\gamma, \eta)}{\partial \eta \partial \partial}<0$.

\section{Data and Methods}

In this section we re-visit, empirically, the explanatory power of the different factors that may be affecting the decentralization process with an especial emphasis on our measures of geographical fragmentation. To conduct this analysis, we have put together an unbalanced panel dataset for 91 countries for the period 1960-2007. Due to missing observations on some variables, the sample size actually varies across estimations. We averaged the values for 5 year periods in order to smooth the data over the macro-economic cycle and also to allow us to focus on the long run effects. Next, we discuss the variables and the empirical strategy we used in our estimations.

As discussed by Panizza (1999) and Oates (1972), among many others, the main problem when empirically examining decentralization is finding a method to quantify the activity of local governments that results from autonomous decision making in expenditure decisions and revenues raising through own taxes. In practice the data available do not allow us to measure true levels of autonomy, especially at the cross country level. In the estimations we use the typical measures of

\footnotetext{
${ }^{8}$ Given our focus on the role of geography we do not focus in several other implications from the equation. However it is easy to see that decentralization would be enhanced by income growth $(\mathrm{Y})$, population growth $(\mathrm{L})$, or the costs of having a centralized system $(\mathrm{F})$.
} 
fiscal decentralization (following Pryor (1968), Oates (1972), Panizza (1999), Martinez-Vazquez and Timofeev (2009) among many others). We define decentralization ratios as the percentage of revenues and expenditures of the sub national governments with respect to the total revenues and expenditures of the public sector from 1960 to $2007 .{ }^{9}$

We incorporate other determinants of fiscal decentralization that have been found consistently in the previous literature to play a significant role. Several studies have examined the main determinants of fiscal decentralization, using a fairly consistent set of variables. One of the commonly used variable is a proxy for the level of development. Decentralization may itself be 'a superior good, the demand for which is likely to grow with per capita income' (Bahl and Linn, 1992). As people become richer, more educated, and more urbanized, they may have more time and a greater motivation to participate in making local political decisions. They may also become more skilled at organizing to pressure the central government to devolve authority and fiscal resources. Also, increases in development may induce a shift in tastes towards public goods and services that are most efficiently provided locally. Bahl and Nath (1986), Letelier (2005), Martinez-Vazquez and Timofeev (2009) and Freikman (2005) find a positive relation between economic development and fiscal decentralization. However, this result is not conclusive, Oates (1972) find a negative relation between economic development and fiscal decentralization and Panizza (1999), finds that the effect differs when outliers are excluded from the analysis. This calls for the inclusion of proxies for economic development in our analysis; therefore we include GDP per capita and infant mortality in the controls.

As Alesina and Spalaore (1997), along with Triesman (2006) and Martinez-Vazquez and

\footnotetext{
${ }^{9}$ The most commonly used source for measuring fiscal decentralization is the Government Financial Statistics publication by the International Monetary Fund. It should be noted that as Letelier (2005) argues, while there are some missing values on the Fiscal Decentralization information from GFS, there is no evidence of a systematic measurement error across countries. Therefore, regression results should not be affected as long as the sample is large enough, which is our case.
} 
Timofeev (2009) argue, institutional variables play a key role in the design of the state; thus some empirical studies of the determinants of decentralization also include the extent of democracy as control variables but results tend to be ambiguous. We include controls such as a political rights and the level of corruption in the analysis in order to control for institutional support of the state. Some studies have suggested that there is a natural affinity between political rights and decentralization; political participation at the local level might educate citizens in democratic practices and lead them to push for higher levels of political rights. At the same time, strong local governments might serve as a check on abusive central authorities and would push for better social controls. In this sense, less corrupt countries would push for stronger local governments, implying higher levels of fiscal decentralization. For example, across Eastern Europe, the collapse of regimes in which power was centralized in the communist party prompted a strong demand for autonomous local selfgovernment (World Bank, 2001).

As presented in the theoretical framework, preferences play a key role on any decentralization process. Panizza (1999), Letelier (2005) and Martinez-Vazquez and Timofeev (2009) argue that ethnic fractionalization may capture differences in preferences of individuals, which is basically an economic efficiency argument since tastes for public goods and services are likely to vary across ethnic groups. Treisman (2006) states an additional argument towards the inclusion of ethnic variables based on practical politics. He argues that where ethnic divisions are politicized (and ethnic groups are territorially compact), decentralizing authority over such contentious policy issues as education and culture may help to restrain communal violence or even prevent civil war. To be credible, policy decentralization must have some fiscal component. Thus, to preserve stability, central elites in more ethnically divided societies may choose a higher level of fiscal decentralization. Of course, they also may not. Central leaders may care more about other goals-retaining fiscal resources at the center, for instance-than about avoiding communal violence. We employ an ethno 
-linguistic fractionalization index from the Department of Geodesy and Cartography of the State Geological Committee of the Soviet Union, originally published in the Atlas Narodov Mira (1964) and then reported by Taylor and Hudson (1972). This measure has been used previously in similar studies such as Panizza (1999), Letelier (2005) and Martinez-Vazquez and Timofeev (2009).

In sum, in addition to geographical diversity as discussed below, we employ the following set of control variables: GDP per capita, infant mortality, several institutional variables such as corruption index and democracy, and ethnic fractionalization. .

\section{Measuring the role of geography}

In order to control for the role of geography we considered a variety of measures. Following the empirical approaches from the economic geography literature in Sachs (2000) and Krugman (1995), and, and from the fiscal decentralization literature in Treisman (2006) and Martinez-Vazquez and Timofeev (2009), we test the effect of country size (area.) ${ }^{10}$ The expected relationship behind the inclusion of this variable is that preferences and access to markets may be more difficult in larger countries leading to higher decentralization levels. In a similar vein we control for the role of “insularity” using the distance to nearest port variable. As Gallup and Sachs (1999) argue, landlocked countries show lower levels of development and resemble weaker institutions. This factor could lead to expect a negative correlation between distance to ports and our fiscal decentralization variables.

As Gallup and Sachs (1999), Lora et al. (2003) and Mellinger et al. (2000) show, land elevation and ecozones differences are geographical factors that directly affect preferences and countries' institutional design. A highly geographically diverse country would be expected to have different public good provision needs due to the environment; these needs are likely to be reflected

\footnotetext{
${ }^{10}$ Given that there is a correlation between the geographical variables and the area variable we regress the geographical variables on area and use the residuals of these in the regressions.
} 
in difference in preferences. At the same time a geographically fragmented country will have problems with implementing access and provision of public goods for its citizens, thus affecting the institutional design of the public sector. In this sense, we use the distribution of population per elevation, and the distribution of climate area to control for in-country geographical asymmetries. ${ }^{11}$

The geographical diversity of countries leads to different degrees of geographical fragmentation, which are reflected in a variety of ways, such as patterns of population settlements. In order to capture synthetically these differences in geographic diversity, we construct a geographical fragmentation index. The essence of the index is provided by the weighted probability that two individuals taken at random do not live in similar altitude zones, with the weight matrix calculated as the average distance between altitudes. Thus the index is simply calculated as $1-$ $\sum_{j=1}^{J} \sum_{i=1}^{N}\left(w_{i j} \frac{n_{i}}{N}\right)^{2}$, where $\frac{n_{i}}{N}$ is the share of population by elevation and $w_{i j}$ measures the distance between altitude $i$ and altitude $j$. This measure goes from zero, which corresponds to a case where all the population is settled in the same altitude zone, to one which corresponds to the implausible case where each individual lives in different altitudes. In general, geographical fragmentation will increase with the number of altitude-zones and the more equal weights for each group. ${ }^{12}$ It can also be the case that geographical fragmentation is enhanced with country size, and to allow for that we interact the geographical fragmentation index with country land area. Figure 1 shows the geographical fragmentation index ranked from countries that are less fragmented (i.e. Belarus, Paraguay) to countries that show high levels of geographical fragmentation (i.e. Colombia, China). The results that our geographical fragmentation index produces go in line with the ones found by Lora et al. (1993) for Latin America.

\footnotetext{
11 This is based on the Koppen-Geiger temperature index. These data were kindly provided by CIESIN at Columbia University.

12 The methodology applied for the index is similar to the one applied by Lora et. al. (2003) for geography, and Hudson (1972) for population.
} 


\section{Figure 1: Map of geographical fragmentation index}

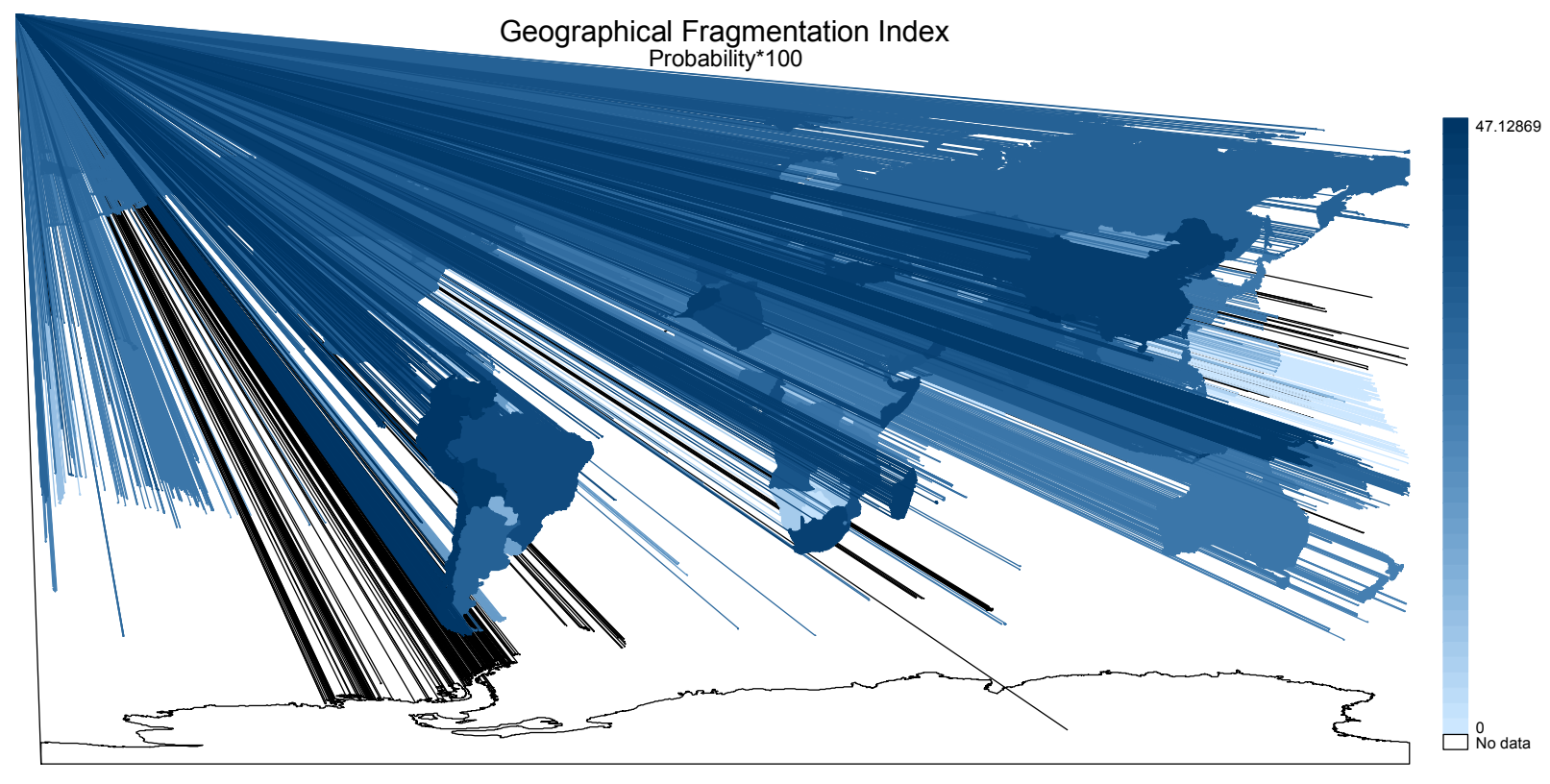

Source: Authors estimations

In addition to the geographical fragmentation index, and in order to get more robust results, we construct Gini distribution indexes for in-country elevation and climate. A lower Gini index would show that the country is more geographically homogenous in the sense that all areas tend to have more similar climate zones or elevations. We also estimate the variation (standard deviation) of the in-country elevation; for example, higher variance on elevation would indicate that the country has a more non-homogenous topography. ${ }^{13}$

In sum, and according to predictions of our theoretical framework, countries with higher geographical fragmentation would have more diverse preferences for public goods and therefore be more decentralized in comparison to countries with more homogeneous preferences. Hence, we would expect a positive correlation between the geographical fragmentation index (where higher

\footnotetext{
13 We also considered several other variables related to geography. For example, we tested for the role of "insularity" using the distance to nearest port variable. However, this and other potential variables proved to be not significant and where not included in the final regressions.
} 
values represent higher geographical fragmentation) and our fiscal decentralization measures. In addition, from the theoretical framework we would expect bigger countries to have higher levels of decentralization.

\section{Empirical Approach}

For the empirical methodology we use first, straight forward pooled OLS estimation as in Oates (1972) and Panizza (1999), and second, panel data estimation, as in Arzaghi and Henderson (2002), Triesman (1998) and Letelier (2005) on an unbalanced panel. We recognize that OLS regressions can have various flaws; however we present them in order to be able to compare our results with those in previous work. In the estimation, we also allow for the potential endogeneity of GDP used as a control variable due to the possibility of some "contagion" effect of this variable that could lead to bias on the coefficients of the other variables. ${ }^{14}$ Not considering this problem, would result in inconsistent parameters. Therefore, we employ the Hausman-Taylor procedure. ${ }^{15}$ This estimator is an IV estimator that additionally enables the coefficients of time-invariant regressors to be estimated; given the data availability and the nature-time invariant-- of our geographical fragmentation index, the Hausman-Taylor procedure is a good alternative to estimate the model. It does so by making the assumption that some regressors are uncorrelated with the fixed effect, which is a plausible for the geographical fragmentation index.

We begin with the following empirical specification ${ }^{16}$ :

$$
F D_{i t}=\alpha_{0}+\beta_{1} X_{i t}+\beta_{2} Z_{i}+\varepsilon_{i t}
$$

\footnotetext{
14 See, for example, Martinez-Vazquez and McNab (2007).

15 The Hausman-Taylor procedure helps correct for endogeneity when fixed effects are present. This methodology is particularly useful when it's not possible to find a good instrumental variable and one needs to study the effect of timeinvariant variables.

16 This is substantially the estimating equation used in Panizza (1999), Arzaghi and Henderson (2005), and others.
} 
Where $F D_{i t}$ represents the fiscal decentralization measures (revenues and expenditures) as defined in the previous section, $X_{i t}$ is the set of control variables described before, $Z_{i}$ the set of country specific variables including the geographical factors.

\section{Results}

In this section we discuss first our main results for the role of geography in fiscal decentralization; next we explore how these results are modified when we allow for infrastructure development to interact with geography; and finally we perform several robustness tests for our findings.

\section{Primary Results}

This section presents in table 1 the results from the OLS and panel Hausman-Taylor estimations. As discussed in the previous sections, we use subnational expenditure as a percentage of total expenditure and subnational revenue as a percentage of total revenue as dependent variables, and examine the effect of the log of GDP per capita, infant mortality index, index of ethnic fractionalization, indexes of rule of law and corruption, the log of area and our constructed indexes of geographical fragmentation.

Regarding our variables of interest related to geography, as the theoretical framework predicted we find positive effects for the most part. As found in the previous literature, larger countries (proxied by area size), tend to be more fiscally decentralized. This result is strong and unambiguously positive across all specifications, whether fiscal decentralization is measured by a subnational expenditure or revenue share, and the estimated coefficients do not change significantly when using different econometric methodologies. In fact the size of the effect does not differ by much suggesting that while larger countries tend to decentralize more, there are no significant 
differences between revenue and expenditure decentralization. Regarding our insularity measure, we find, for the most part, that distance to the port is significant and negatively correlated with our measures of fiscal decentralization (especially our expenditure measure). This finding goes in line with the argument posited by Gallup and Sachs (1999) who relate insularity with growth and institutions and find a negative correlation.

Our constructed index of geographical fragmentation presents a positive and significant effect, especially when looking at the sub-national expenditure measure. As the probability of randomly picking two individuals belonging to the same geographical region increases, so does the sub national expenditure decentralization measure. Columns (1), (5) and (9) from table 6 show that this effect is consistent across different empirical methodologies. Even though the effect is slightly reduced in size and significance when controlling for the GDP's endogeneity, it still remains significant. The results for the sub national revenue measure are not as strong as the ones found for expenditure decentralization; this result may partly reflect the fact that heterogeneity of preferences for taxation is usually less than for expenditures. The interaction between our geographical fragmentation index and the size of the country are more significant than the variables constructed using the index alone, yet smaller in size. These results as a whole confirm the importance of geography when examining the determinants of the extent of fiscal decentralization. 


\section{Table 1: Fiscal decentralization determinants}

\begin{tabular}{|c|c|c|c|c|c|c|c|c|c|c|c|c|}
\hline & \multicolumn{4}{|c|}{ OLS } & \multicolumn{4}{|c|}{ Panel } & \multicolumn{4}{|c|}{ Hausman Taylor } \\
\hline & \multicolumn{2}{|c|}{ Sub Expenditure } & \multicolumn{2}{|c|}{ Sub Revenue } & \multicolumn{2}{|c|}{ Sub Expenditure } & \multicolumn{2}{|c|}{ Sub Revenue } & \multicolumn{2}{|c|}{ Sub Expenditure } & \multicolumn{2}{|c|}{ Sub Revenue } \\
\hline & (1) & (2) & (3) & (4) & (5) & (6) & (7) & (8) & (9) & (10) & (11) & (12) \\
\hline GDP per capita & 0.0697 & 0.0686 & 0.0414 & 0.041 & $0.0698^{*}$ & $0.0696^{*}$ & $0.0587^{*}$ & $0.0589 *$ & $0.0959^{* *}$ & $0.0958^{* *}$ & $0.1103^{*}$ & 0.1102 \\
\hline & $(0.0423)$ & $(0.0416)$ & $(0.049)$ & $(0.0488)$ & $(0.0400)$ & $(0.0397)$ & $(0.0348)$ & $(0.0348)$ & $(0.0456)$ & $(0.0457)$ & $(0.0672)$ & $(0.0672)$ \\
\hline Infant mortality & $\begin{array}{l}-0.0001 \\
(0.0011)\end{array}$ & $\begin{array}{l}-0.0002 \\
(0.0011)\end{array}$ & $\begin{array}{l}-0.0006 \\
(0.0011)\end{array}$ & $\begin{array}{l}-0.0007 \\
(0.0011)\end{array}$ & $\begin{array}{l}-0.0008 \\
(0.0011)\end{array}$ & $\begin{array}{l}-0.0009 \\
(0.0011)\end{array}$ & $\begin{array}{l}-0.0011 \\
(0.0011)\end{array}$ & $\begin{array}{l}-0.0012 \\
(0.0011)\end{array}$ & $\begin{array}{l}-0.0005 \\
(0.0014)\end{array}$ & $\begin{array}{l}-0.0006 \\
(0.0014)\end{array}$ & $\begin{array}{l}-0.0004 \\
(0.0014)\end{array}$ & $\begin{array}{l}-0.0004 \\
(0.0015)\end{array}$ \\
\hline Corruption & $\begin{array}{r}-0.0046^{* *} \\
(0.0022)\end{array}$ & $\begin{array}{r}-0.0056^{* *} \\
(0.0028)\end{array}$ & $\begin{array}{c}-0.0152 * \\
(0.0081)\end{array}$ & $\begin{array}{l}-0.0157 \\
(0.0343)\end{array}$ & $\begin{array}{c}-0.0161 * \\
(0.0091)\end{array}$ & $\begin{array}{c}-0.0169 * \\
(0.0090)\end{array}$ & $\begin{array}{l}-0.0232 \\
(0.0312)\end{array}$ & $\begin{array}{l}-0.0236 \\
(0.0311)\end{array}$ & $\begin{array}{r}-0.0217^{* *} \\
(0.0093)\end{array}$ & $\begin{array}{r}-0.0227^{* * *} \\
(0.0012)\end{array}$ & $\begin{array}{c}-0.0289 * \\
(0.0170)\end{array}$ & $\begin{array}{r}-0.0295^{*} \\
(0.0160)\end{array}$ \\
\hline Political Right & $\begin{array}{r}-0.0283^{*} \\
(0.0162)\end{array}$ & $\begin{array}{r}-0.0281 * \\
(0.0158)\end{array}$ & $\begin{array}{r}-0.0275^{* *} \\
(0.0121)\end{array}$ & $\begin{array}{r}-0.0269 * \\
(0.0158)\end{array}$ & $\begin{array}{c}-0.0255^{*} \\
(0.0133)\end{array}$ & $\begin{array}{c}-0.0254^{*} \\
(0.0131)\end{array}$ & $\begin{array}{r}-0.0248^{*} \\
(0.0150)\end{array}$ & $\begin{array}{c}-0.0244 * \\
(0.0148)\end{array}$ & $\begin{array}{l}-0.025^{*} \\
(0.0149)\end{array}$ & $\begin{array}{c}-0.0253^{*} \\
(0.0150)\end{array}$ & $\begin{array}{c}-0.0229 * \\
(0.0126)\end{array}$ & $\begin{array}{r}-0.0228^{*} \\
(0.0120)\end{array}$ \\
\hline Ethnic Fractionalization & $\begin{array}{r}0.0534^{* *} \\
(0.0270)\end{array}$ & $\begin{array}{c}0.0489 * * \\
(0.0240)\end{array}$ & $\begin{array}{r}0.0963 \\
(0.1129)\end{array}$ & $\begin{array}{r}0.0966 \\
(0.1147)\end{array}$ & $\begin{array}{r}0.0831 \\
(0.1263)\end{array}$ & $\begin{array}{r}0.0787 \\
(0.1282)\end{array}$ & $\begin{array}{l}0.1074 * \\
(0.0610)\end{array}$ & $\begin{array}{l}0.1085^{*} \\
(0.0587)\end{array}$ & $\begin{array}{r}0.0446 * * \\
(0.0213)\end{array}$ & $\begin{array}{l}0.0341 * \\
(0.0200)\end{array}$ & $\begin{array}{r}0.0806 \\
(0.1346)\end{array}$ & $\begin{array}{r}0.0772 \\
(0.1355)\end{array}$ \\
\hline Distance to Ports & $\begin{array}{r}-0.0416^{*} \\
(0.0215)\end{array}$ & $\begin{array}{r}-0.0399 * \\
(0.0217)\end{array}$ & $\begin{array}{r}-0.0276^{* *} \\
(0.0136)\end{array}$ & $\begin{array}{l}-0.026^{* *} \\
(0.0124)\end{array}$ & $\begin{array}{c}-0.0415^{*} \\
(0.0220)\end{array}$ & $\begin{array}{c}-0.0394^{*} \\
(0.0220)\end{array}$ & $\begin{array}{l}-0.0254 \\
(0.0247)\end{array}$ & $\begin{array}{l}-0.0234 \\
(0.0254)\end{array}$ & $\begin{array}{r}-0.0629 * \\
(0.0383)\end{array}$ & $\begin{array}{r}-0.05627 \\
(0.0385)\end{array}$ & $\begin{array}{l}-0.0405 \\
(0.0381)\end{array}$ & $\begin{array}{l}-0.0399 \\
(0.0384)\end{array}$ \\
\hline Area & $\begin{array}{r}0.0713^{* * *} \\
(0.0184)\end{array}$ & $\begin{array}{l}0.05^{* * *} \\
(0.0170)\end{array}$ & $\begin{array}{r}0.0697^{* * *} \\
(0.0206)\end{array}$ & $\begin{array}{r}0.0545^{* * *} \\
(0.0202)\end{array}$ & $\begin{array}{r}0.0742^{* * *} \\
(0.0211)\end{array}$ & $\begin{array}{r}0.0514^{* * *} \\
(0.0193)\end{array}$ & $\begin{array}{r}0.0767^{* * *} \\
(0.0240)\end{array}$ & $\begin{array}{r}0.0606^{* * *} \\
(0.0234)\end{array}$ & $\begin{array}{r}0.0648^{* * *} \\
(0.0173)\end{array}$ & $\begin{array}{r}0.0475^{* * *} \\
(0.0114)\end{array}$ & $\begin{array}{r}0.0673^{* * *} \\
(0.0176)\end{array}$ & $\begin{array}{r}0.0553^{* * *} \\
(0.0123)\end{array}$ \\
\hline Geographical Fragmentation Index (GFI) & $\begin{array}{r}0.0143^{* * *} \\
(0.0040)\end{array}$ & & $\begin{array}{c}0.0101 * * \\
(0.0045)\end{array}$ & & $\begin{array}{r}0.0157^{* * *} \\
(0.0041)\end{array}$ & & $\begin{array}{c}0.0107^{* *} \\
(0.0046)\end{array}$ & & $\begin{array}{c}0.0127^{* *} \\
(0.0061)\end{array}$ & & $\begin{array}{r}0.0083 \\
(0.0052)\end{array}$ & \\
\hline Geo.Frag*Area & & $\begin{array}{r}0.0062^{* * *} \\
(0.0022)\end{array}$ & & $\begin{array}{r}0.0049^{* *} \\
(0.002)\end{array}$ & & $\begin{array}{r}0.0062^{* * *} \\
(0.0021)\end{array}$ & & $\begin{array}{l}0.004^{* *} \\
(0.0028)\end{array}$ & & $\begin{array}{r}0.0061^{* * *} \\
(0.002)\end{array}$ & & $\begin{array}{r}0.0038 \\
(0.0025)\end{array}$ \\
\hline Constant & $\begin{array}{l}-0.4278 \\
(0.4417)\end{array}$ & $\begin{array}{l}-0.1629 \\
(0.4577)\end{array}$ & $\begin{array}{l}-0.1546 \\
(0.5226)\end{array}$ & $\begin{array}{r}0.0339 \\
(0.5274)\end{array}$ & $\begin{array}{l}-0.4375 \\
(0.3402)\end{array}$ & $\begin{array}{l}-0.1602 \\
(0.3578)\end{array}$ & $\begin{array}{l}-0.2984 \\
(0.4245)\end{array}$ & $\begin{array}{l}-0.1042 \\
(0.4295)\end{array}$ & $\begin{array}{l}-0.2847 \\
(0.7758)\end{array}$ & $\begin{array}{l}-0.0694 \\
(0.7536)\end{array}$ & $\begin{array}{l}-0.4964 \\
(0.8112)\end{array}$ & $\begin{array}{l}-0.3476 \\
(0.7962)\end{array}$ \\
\hline Region and time dummies & YES & YES & YES & YES & YES & YES & YES & YES & YES & YES & YES & YES \\
\hline N. of cases & 338 & 338 & 335 & 335 & 338 & 338 & 335 & 335 & 338 & 338 & 335 & 335 \\
\hline
\end{tabular}

Source: Own Estimations 
The results for the other control variable are largely in line with those found in the previous literature. As was found in a good number of previous papers (Wheare, 1953; Bahl and Linn, 1992; Panizza, 1999; Arzaghi and Henderson, 2005; Triesman, 2006; Martinez-Vazquez and Timofeev, 2009), and as predicted by our theoretical framework, the positive sign of the log of GDP per capita shows that countries with higher levels of income tend to be more decentralized. However, the results vary across specifications and the changes tend to be quite dramatic. Contrary to Oates (1972) and Bahl and Linn (1992) in the simple OLS model, we do not find a significant relation between GDP and our fiscal decentralization measures. Though, we do find a stronger and significant relation of GDP with our expenditure decentralization measure when we impose a panel structure and correct for the potential endogeneity. The estimated relationship with revenue decentralization is weaker and slightly less significant for most of our specifications. Our infant mortality variable, a proxy for the level of development, does not show significant results. We do not find significant effects of the political rights measure (for either measure of decentralization-expenditure and revenue), while we do find a weak negative effect for the corruption variable, indicating that less corrupt countries (with better institutions) tend to have higher levels of fiscal decentralization. ${ }^{17}$

The positive results of the ethnic fractionalization variable are in line with the findings of Panizza (1999), Letelier (2005) and, to a less extent, Treisman (2006). Higher levels of fractionalization (measured by ethno-linguistic fractionalization) lead to higher levels of fiscal decentralization. However, this effect holds only for the expenditure measure of decentralization and is stronger when controlling for the potential endogeneity of the GDP. A plausible interpretation of this result is that greater ethnic diversity would be reflected on different

\footnotetext{
${ }^{17}$ We also estimated the models excluding the political rights variables and the results did not change significantly.
} 
expenditure needs of the people, and therefore this would affect the degree of sub-national expenditure decentralization measure in a more significant way vis-à-vis revenue decentralization.

\section{Testing the effect of infrastructure}

As discussed above, we may expect the effect of geography on fiscal decentralization to be attenuated by improvements in physical infrastructure as time and physical "distances" are reduced.

We aim to capturing these effects through the inclusion of variables measuring the level of development of physical infrastructure interacted with the geographical fragmentation index. A priori, one would expect the sign of the coefficient for geographical fragmentation index to be positive (and significant), while the interaction between the infrastructure variables and the index to be negative (and significant). The level of infrastructure development is approximated for each country by three variables: the percentage of paved roads (RPV), the log of total kilometers of roads (RTKM) and log of length of rail tracks (TRAK). Table 2 presents the estimation results of the effect geographical fragmentation and land area interacted with the three indexes of infrastructure development.18 The results show that to some extent better infrastructure reduces the effect of geography on fiscal decentralization. However, this only holds for the log of kilometers of paved roads and the log of kilometers of rail tracks in the country. Once we are controlling for size of the country, the negative and slightly significant sign of the interaction term of length of roads and the geographical fragmentation index appears to offer support to the hypothesis that higher levels of infrastructure development should reduce the effect of geography on decentralization. However, because the coefficients that we find, when significant, are very small in size-and often they not significant--, we can conclude that while infrastructure plays some role on reducing the impact of

\footnotetext{
${ }^{18}$ Tables 4 and 5 show the full results with all other variables.
} 
geography on fiscal decentralization, overall this counterbalancing effect leaves the role of geography

largely unchanged.

Table 2: Examining the effect of infrastructure

\begin{tabular}{|c|c|c|c|c|c|c|}
\hline \multicolumn{7}{|c|}{ Subnational Revenue/GDP } \\
\hline & $(1)$ & $(2)$ & (3) & (4) & (5) & (6) \\
\hline Geographical Fragmentation Index (GFI) & $\begin{array}{r}0.0198^{* * *} \\
(0.0041)\end{array}$ & $\begin{array}{r}0.0172^{* * *} \\
(0.0043)\end{array}$ & $\begin{array}{r}0.0137 * * \\
(0.0060)\end{array}$ & & & \\
\hline$\%$ of paved roads $*$ GFI & $\begin{array}{r}-0.00001^{* *} \\
(0.00001)\end{array}$ & & & & & \\
\hline $\log ($ Roads $\mathrm{km}) * \mathrm{GFI}$ & & $\begin{array}{r}0.0002 \\
(0.0008)\end{array}$ & & & & \\
\hline $\log ($ length of track rails $) *$ GFI & & & $\begin{array}{r}-0.0223^{*} \\
(0.0201)\end{array}$ & & & \\
\hline GFI*Area & & & & $\begin{array}{r}0.0008^{* * *} \\
(0.0002)\end{array}$ & $\begin{array}{r}0.0007 * * * \\
(0.0002)\end{array}$ & $\begin{array}{r}0.0007 * * * \\
(0.0002)\end{array}$ \\
\hline$\%$ of paved roads $*$ GFI*Area & & & & $\begin{array}{r}-0.0001^{* *} \\
(0.0000)\end{array}$ & & \\
\hline $\log ($ Roads $\mathrm{km}) *$ GFI $*$ Area & & & & & $\begin{array}{r}0.000001 \\
(0.0000)\end{array}$ & \\
\hline $\log ($ length of track rails $) *$ GFI $*$ Area & & & & & & $\begin{array}{r}-0.0016 * \\
(0.0010)\end{array}$ \\
\hline Controls & YES & YES & YES & YES & YES & YES \\
\hline N. of cases & 165 & 172 & 215 & 165 & 172 & 215 \\
\hline \multicolumn{7}{|c|}{ Subnational Expenditure/GDP } \\
\hline & $(7)$ & $(8)$ & (9) & $(10)$ & $(11)$ & $(12)$ \\
\hline Geographical Fragmentation Index (GFI). & $\begin{array}{r}0.0128^{* * *} \\
(0.0040)\end{array}$ & $\begin{array}{r}0.0124 * * * \\
(0.0041)\end{array}$ & $\begin{array}{r}0.01 * \\
(0.0060)\end{array}$ & & & \\
\hline$\%$ of paved roads $*$ GFI & $\begin{array}{r}-0.00001 * * \\
(0.00001)\end{array}$ & & & & & \\
\hline $\log ($ Roads $\mathrm{km}) *$ GFI & & $\begin{array}{r}0.0007 \\
(0.0006)\end{array}$ & & & & \\
\hline $\log ($ length of track rails $) *$ GFI & & & $\begin{array}{r}-0.0242 * \\
(0.0202)\end{array}$ & & & \\
\hline GFI*Area & & & & $\begin{array}{r}0.0006^{* * *} \\
(0.0002)\end{array}$ & $\begin{array}{r}0.0005^{* * *} \\
(0.0002)\end{array}$ & $\begin{array}{r}0.0005^{* * *} \\
(0.0002)\end{array}$ \\
\hline$\%$ of paved roads $*$ GFI*Area & & & & $\begin{array}{r}-0.00001^{* *} \\
(0.0000)\end{array}$ & & \\
\hline $\log ($ Roads $\mathrm{km}) *$ GFI $*$ Area & & & & & $\begin{array}{r}0.000001 \\
(0.0000)\end{array}$ & \\
\hline $\log ($ length of track rails $) *$ GFI $*$ Area & & & & & & $\begin{array}{r}-0.0018^{*} \\
(0.0010)\end{array}$ \\
\hline Controls & YES & YES & YES & YES & YES & YES \\
\hline N. of cases & 162 & 169 & 215 & 162 & 169 & 215 \\
\hline
\end{tabular}




\section{Robustness}

To ensure that our results are no an artifact resulting from the construction of the geographical fragmentation index, ${ }^{19}$ we conduct a series of estimation with less sophisticated -yet adequatevariables for geographical fragmentation. Thus we calculate the standard deviation of population distributed by elevation, the distribution Gini coefficient for the same variable, ${ }^{20}$ and the Gini distribution coefficient for climate variable and estimate the same model as with the index of geographical fragmentation in Table 1 . The results are presented in table 3 only for the variables of interest shows a summary of the results for these estimations.

Columns (1) and (2) in table 3 show the effect the standard deviation of population distributed by elevation as well as the Gini measures. The standard deviation aims to capture in country deviations from the average elevation. The results for the standard deviation of the elevation shows a positive correlation with both fiscal decentralization indicators and is statistically significant. Higher standard deviation of the distribution of population by elevation is positively, correlated with higher levels of fiscal decentralization confirming our hypothesis. While the standard deviation of elevation is a simple measure of dispersion and can be subject to criticism, and our geographical fragmentation index could be criticize for being too complex; we construct a more common measure of dispersion for elevation which is a Gini coefficient. This Gini coefficient measures the distribution of the elevation weighted by the share of population. Due to the characteristics of our data, higher levels of our Gini coefficient would imply that the country is geographically heterogeneous, and lower levels of the Gini coefficient would mean lower levels of geographical fragmentation. The results of the Gini coefficient confirm our hypothesis; higher levels of our Gini-

\footnotetext{
19 The construction of this type of indexes is usually subject to some caveats, such as the definition of weights.

${ }^{20}$ A lower Gini index would indicate that the country is geographically more homogenous in the sense of more similar climate zones or elevations.
} 
elevation index are positively correlated with higher fiscal decentralization, measure both on the expenditure and revenue side, being the first one more significant than the later one. Similar correlation is showed with the Gini-Climate indicator, however the effect is not significant. .

Table 3: Hausman Taylor Robustness estimation

\begin{tabular}{|c|c|c|c|c|c|c|c|c|}
\hline & \multicolumn{4}{|c|}{ Subnational Expenditures/ GDP } & \multicolumn{4}{|c|}{ Subnational Revenues / GDP } \\
\hline & $(1)$ & & (3) & (4) & $(5)$ & $(6)$ & $(7)$ & (8) \\
\hline SD_Elevation & & 0001) & & & & $\begin{array}{l}002^{* *} \\
(0.0001)\end{array}$ & & \\
\hline Gini_Climate & & & $\begin{array}{r}0.1121 \\
(0.2108)\end{array}$ & & & & $\begin{array}{r}0.0052 \\
(0.2093)\end{array}$ & \\
\hline Gini_Elevation & & & & $\begin{array}{l}1336^{*} \\
(0.0725)\end{array}$ & & & & $\begin{array}{r}0.0056 \\
(0.2510)\end{array}$ \\
\hline Controls & YES & YES & YES & YES & YES & YES & YES & YES \\
\hline N. of cases & 338 & 338 & 316 & 338 & 335 & 335 & 313 & 335 \\
\hline
\end{tabular}

In sum, table 3 shows that the results for the relation between geography and fiscal decentralization are relatively robust to the definition of geographical disparities. Countries which are more geographically different tend to decentralize more. We find the stronger positive and fairly significant effects for the standard deviation and the Gini coefficient for the distribution of elevation and much weaker effects for the standard deviation and Gini coefficient for the distribution of climate zones. It is quite reasonable that disparities in elevation matter more than disparities in climate. 


\section{Conclusion}

In this paper we re-examine in depth the effect of geography as a determinant of fiscal decentralization. Theoretically, we draw on the Arzaghi and Henderson (2002) and Panizzas (1999) models in order to motivate the main determinants of decentralization with a special interest in the role of geography. The theoretical model predicts that countries with higher geographic dissimilarities will be more decentralized. We use a rich dataset, and multiple econometric specifications to empirically examine the determinants of fiscal decentralization with special focus on geography. Empirically, we follow the mainstream of fiscal decentralization determinants and test the effect of development variables such as GDP, along with institutional and ethnic variables such as rule of law, corruption, political rights and ethno linguistic fractionalization.

Following Lora et al. (2003) and Hudson (1972), we construct a geographical fragmentation index that aims to capture the probability that two individuals taken at random do not live in similar altitude zones. In the analysis we employ two different measures of fiscal decentralization, subnational expenditure as percentage of GDP and revenue as percentage of GDP.

Although our overarching results on the determinants of fiscal decentralization are similar to previous studies, we find a clear positive effect of geographical variables on fiscal decentralization. Higher levels of geographical fragmentation are significantly associated with higher levels of fiscal decentralization, measured both on the expenditure and the revenue side. These results are quite robust to different econometric methodologies and also to different geographical measures.

The implications of this result are twofold: First, our results add to the existent body of literature on fiscal decentralization by considering a very important measure that aims to capture geographical differences. More importantly our findings add to the evidence that geography matters 
in a development process. Second, the strong correlation found between geographical variables and fiscal decentralization could be used for correcting endogeneity problems in future works, where fiscal decentralization is endogenous by using geographic fragmentation measures as an instrument of fiscal decentralization. However, the use of geography as an instrument for decentralization is limited to estimation approaches that do not require time variant variables. 


\section{References}

Alesina, A. and E. Spolaore (1997). "On the Number and Size of Nations*." Quarterly Journal of Economics 112(4): 1027-1056.

Arellano, M. and S. Bond (1991). "Some tests of specification for panel data: Monte Carlo evidence and an application to employment equations." The Review of Economic Studies 58(2): 277.

Arzaghi, M. and J. V. Henderson (2005). "Why countries are fiscally decentralizing." Journal of Public Economics 89(7): 1157-1189.

Bahl, R. (1999). "Implementation rules for fiscal decentralization." International Studies Program Working Paper 30.

Bahl, R. W., J. F. Linn, et al. (1992). Urban public finance in developing countries, Published for the World Bank [by] Oxford University Press.

Bahl, R. W. and S. Nath (1986). "Public expenditure decentralization in developing countries." Environment and Planning C: Government and Policy 4(4): 405-418.

Bardhan, P. and D. Mookherjee (2000). "Capture and governance at local and national levels." The American Economic Review 90(2): 135-139.

Besley, T. and A. Case (1995). "Incumbent behavior: Vote-seeking, tax-setting, and yardstick competition." The American Economic Review 85(1): 25-45.

Besley, T and S. Coate (2003) "Central versus Local Provision of Public Goods: A Political Economy Analysis” Journal of Public Economics. 87(4), 2611-2637.

Bird, R. M. and F. Vaillancourt (1998). Fiscal decentralization in developing countries, Cambridge Univ Pr.

Crosby, A. W. (2004). Ecological imperialism: the biological expansion of Europe, 900-1900, Cambridge Univ Pr.

Fujita, M., P. R. Krugman, et al. (2001). The spatial economy, Mit press.

Fujita, M. and T. Mori (2005). "Frontiers of the New Economic Geography*." Papers in Regional Science 84(3): 377-405.

Gallup, J. L., J. D. Sachs, et al. (1998). Geography and economic development, National Bureau of Economic Research Cambridge, Mass., USA.

Greene, W. H. and C. Zhang (2003). Econometric analysis, Prentice hall New Jersey.

Jones, E. L. (2003). The European miracle: Environments, economies, and geopolitics in the history of Europe and Asia, Cambridge Univ Pr.

Kee, W. S. (1977). "Fiscal decentralization and economic development." Public Finance Review 5(1): 79.

Krugman, P. (1999). "The role of geography in development." International regional science review 22(2): 142.

Krugman, P. R. and A. Venables (1995). The seamless world: a spatial model of international specialization, National Bureau of Economic Research Cambridge, Mass., USA.

Letelier, L. (2005). "Explaining fiscal decentralization." Public Finance Review 33(2): 155.

Lijphart, A. (1977). Democracy in plural societies: A comparative exploration, Yale Univ Pr.

Lockwood, B. (2002) "Distributive Politics and the Benefits of Decentralization", Review of Economic Studies, 69, 313-37, April.

Lora, E., J. L. Gallup, et al. (2003). Is geography destiny?: lessons from Latin America, Stanford Social Sciences.

MacLeod, G. and M. Jones (2001). "Renewing the geography of regions." Environment and planning D 19(6): 669-696. 
Martinez-Vazquez, J. and R. McNab (2003). "Fiscal decentralization and economic growth." World Development 31(9): 1597-1616.

Martinez-Vazquez, J. and A. Timofeev (2009). "A fiscal perspective of state rescaling." Cambridge Journal of Regions, Economy and Society 2(1): 85.

Mellinger, A. D., J. D. Sachs, et al. (2000). "Climate, coastal proximity, and development." The Oxford Handbook of Economic Geography, Oxford University Press, Oxford.

Oates, W. (1985). "Searching for Leviathan: An empirical study." The American Economic Review 75(4): 748-757.

Oates, W. E. (1972). Fiscal federalism, Harcourt Brace Jovanovich New York.

Oates, W. E. (1985). "Searching for Leviathan: An empirical study." The American Economic Review 75(4): 748-757.

Panizza, U. (1999). "On the determinants of fiscal centralization: Theory and evidence." Journal of Public Economics 74(1): 97-139.

Patsouratis, V. A. (1990). "Fiscal decentralization in the EEC countries." Public Finance= Finances publiques 45(3): 423-439.

Pommerehne, W. W. (1976). "Quantitative aspects of federalism: A study of 6 countries."

Pryor, F. L. (1968). Public expenditures in communist and capitalist nations, Irwin.

Rogowski, R. (1987). "Political cleavages and changing exposure to trade." The American Political Science Review: 1121-1137.

Sachs, J. D. (2001). Tropical underdevelopment, National Bureau of Economic Research Cambridge, Mass., USA.

Sepúlveda, C. and J. Martinez-Vazquez (2010). "The Consequences of Fiscal Decentralization on Poverty and Income Inequality." International Studies Program Working Paper Series, at AYSPS, GSU.

Stegarescu, D. (2005). "Public Sector Decentralisation: Measurement Concepts and Recent International Trends." Fiscal studies 26(3): 301-333.

Tanzi, V. (2000). On fiscal federalism: issues to worry about.

Taylor, C. L., D. A. Jodice, et al. (1984). World Handbook of Political and Social Indicators III: 1948-1982, Inter-university Consortium for Political and Social Research [distributor].

Tiebout, C. M. (1956). "A pure theory of local expenditures." The journal of political economy: 416424.

Treisman, D. (2000). "Decentralization and inflation: Commitment, collective action, or continuity." American Political Science Review 94(4): 837-857.

Wasylenko, M. (1987). "Fiscal decentralization and economic development." Public Budgeting \& Finance 7(4): 57-71. 


\section{Appendix}

\section{Table 4: Panel estimation with infrastructure time variant interaction}

\begin{tabular}{|c|c|c|c|c|c|c|c|c|c|c|c|c|}
\hline & \multicolumn{6}{|c|}{ Subnational Expenditure/GDP } & \multicolumn{6}{|c|}{ Subnational Revenue/GDP } \\
\hline & (1) & (2) & (3) & (4) & (5) & (6) & (7) & (8) & (9) & (10) & (11) & (12) \\
\hline \multirow[t]{2}{*}{ Log of GDP Per Capita } & $0.0005^{* *}$ & -0.0001 & $0.0571 * *$ & -0.0003 & 0.0002 & $0.057^{* *}$ & 0.0018 & -0.0033 & $0.0586^{* * *}$ & 0.0028 & -0.0026 & $0.0586^{* * * *}$ \\
\hline & $(0.0002)$ & $(0.0136)$ & $(0.0252)$ & $(0.0167)$ & $(0.0135)$ & $(0.0250)$ & $(0.0209)$ & $(0.0207)$ & $(0.0223)$ & $(0.0206)$ & $(0.0205)$ & $(0.0221)$ \\
\hline \multirow[t]{2}{*}{ Infant mortality } & $-0.0008^{* *}$ & $-0.0009^{* *}$ & 0.0004 & $-0.0008^{* *}$ & $-0.0009^{* *}$ & 0.0004 & -0.001 & -0.0011 & -0.0001 & -0.0011 & -0.0012 & -0.0001 \\
\hline & $(0.0004)$ & (0.0004) & $(0.0009)$ & $(0.0004)$ & (0.0004) & $(0.0009)$ & $(0.0008)$ & $(0.0008)$ & $(0.0007)$ & $(0.0008)$ & $(0.0008)$ & $(0.0007)$ \\
\hline \multirow[t]{2}{*}{ Political Right } & 0.0007 & 0.001 & $-0.0107 *$ & 0.0006 & 0.001 & $-0.0107^{*}$ & -0.0001 & -0.0006 & $-0.0137^{* * *}$ & -0.0001 & -0.0007 & $-0.0138^{* * *}$ \\
\hline & $(0.0021)$ & $(0.0018)$ & $(0.0056)$ & $(0.0022)$ & $(0.0018)$ & $(0.0056)$ & $(0.0059)$ & $(0.0062)$ & $(0.0039)$ & $(0.0058)$ & $(0.0061)$ & $(0.0039)$ \\
\hline \multirow[t]{2}{*}{ Ethno- linguistic Fractionalization } & -0.0497 & 0.0081 & $-0.0083^{* *}$ & -0.0569 & 0.0041 & $-0.0154 *$ & -0.0856 & -0.0097 & $-0.0503 * *$ & -0.0999 & -0.0238 & $-0.0599 * *$ \\
\hline & $(0.0769)$ & $(0.0983)$ & $(0.0041)$ & $(0.0756)$ & $(0.0973)$ & $(0.0081)$ & $(0.0835)$ & $(0.1028)$ & $(0.0210)$ & $(0.0817)$ & $(0.1007)$ & $(0.0251)$ \\
\hline \multirow[t]{2}{*}{ Log Distance to Ports } & $-0.0415^{* * *}$ & $-0.0339 *$ & $-0.0387^{*}$ & $-0.0402 * *$ & $-0.0333 *$ & $-0.036^{*}$ & $-0.0534 * * *$ & $-0.0539 * * *$ & $-0.0465 * *$ & $-0.0525 * * *$ & $-0.0515^{* * *}$ & $-0.0435 * *$ \\
\hline & $(0.0172)$ & $(0.0201)$ & $(0.0206)$ & $(0.0171)$ & $(0.0202)$ & $(0.0209)$ & $(0.0183)$ & $(0.0202)$ & $(0.0215)$ & $(0.0178)$ & $(0.0200)$ & $(0.0211)$ \\
\hline \multirow[t]{2}{*}{ Log Area } & $0.0529 * * *$ & $0.0538^{* * *}$ & $0.049 * * *$ & $0.0323 * * *$ & $0.0352 * * *$ & $0.0288 * * *$ & $0.0526^{* * *}$ & $0.0513^{* * *}$ & $0.0572^{* * *}$ & $0.0274 * * *$ & $0.0281 * * *$ & $0.0329 * * *$ \\
\hline & $(0.0096)$ & $(0.0102)$ & $(0.0133)$ & $(0.0075)$ & $(0.0084)$ & $(0.0071)$ & $(0.0108)$ & $(0.0107)$ & $(0.0138)$ & $(0.0063)$ & $(0.0064)$ & $(0.0079)$ \\
\hline \multirow[t]{2}{*}{ Corruption Index } & -0.002 & 0.0001 & $-0.0017^{* *}$ & -0.002 & 0.0001 & $-0.0017^{* *}$ & 0.0035 & 0.0021 & 0.0024 & 0.0033 & 0.0022 & 0.0024 \\
\hline & $(0.0049)$ & $(0.0035)$ & $(0.0007)$ & $(0.0050)$ & $(0.0035)$ & $(0.0007)$ & $(0.0050)$ & $(0.0049)$ & $(0.0062)$ & $(0.0051)$ & $(0.0049)$ & $(0.0062)$ \\
\hline \multirow[t]{2}{*}{ Geographical Fragmentation Index (GFI) } & $0.0139 * * *$ & $0.0124 * * *$ & & $0.0146^{* * *}$ & & & $0.0189 * * *$ & $0.0168^{* * *}$ & & $0.0176^{* * *}$ & & \\
\hline & $(0.0038)$ & $(0.0042)$ & $(0.0054)$ & & & & $(0.0038)$ & $(0.0040)$ & $(0.0051)$ & & & \\
\hline \multirow[t]{2}{*}{$\%$ of paved roads $*$ GFI } & & $0.00001^{* * *}$ & & & & & 0.000001 & & & & & \\
\hline & 0.0000 & & & & & & $(0.0000)$ & & & & & \\
\hline \multirow[t]{2}{*}{ Log(Roads km) * GFI } & & 0.0006 & & & & & & -0.0001 & & & & \\
\hline & & $(0.0008)$ & & & & & & $(0.0007)$ & & & & \\
\hline \multirow[t]{2}{*}{ Log(length of track rails) $*$ GFI } & & & -0.0074 & & & & & & -0.0084 & & & \\
\hline & & & $(0.0214)$ & & & & & & $(0.0246)$ & & & \\
\hline \multirow[t]{2}{*}{ GFI *Area } & & & & $0.0062^{* * *}$ & $0.0051^{* * *}$ & $0.006 * * *$ & & & & $0.00885^{* * *}$ & $0.0075^{* * *}$ & $0.0089^{* * *}$ \\
\hline & & & & $(0.0001)$ & $(0.0002)$ & $(0.0002)$ & & & & $(0.0001)$ & $(0.0002)$ & $(0.0002)$ \\
\hline \multirow[t]{2}{*}{$\%$ of paved roads $* \mathrm{GFI} *$ Area } & & & & 0.00001 & & & & & & 0.000001 & & \\
\hline & & & & 0.0001 & & & & & & $(0.0000)$ & & \\
\hline \multirow[t]{2}{*}{$\log ($ Roads $\mathrm{km}) *$ GFI $*$ Area } & & & & & 0.0001 & & & & & & 0 & \\
\hline & & & & & $(0.0001)$ & & & & & & $(0.0001)$ & \\
\hline \multirow[t]{2}{*}{$\log ($ length of track rails $) *$ GFI *Area } & & & & & & -0.0005 & & & & & & -0.0007 \\
\hline & & & & & & $(0.0018)$ & & & & & & $(0.0022)$ \\
\hline \multirow[t]{2}{*}{ Constant } & 0.0211 & -0.0129 & -0.5696 & 0.2605 & 0.1993 & -0.3443 & -0.0322 & 0.0339 & $-0.5997 * *$ & 0.2578 & 0.2911 & -0.3292 \\
\hline & $(0.2172)$ & $(0.2238)$ & $(0.3790)$ & $(0.2114)$ & $(0.2092)$ & $(0.3744)$ & $(0.2378)$ & $(0.2458)$ & $(0.2862)$ & $(0.2266)$ & $(0.2358)$ & $(0.2740)$ \\
\hline N. of cases & 162 & 169 & 215 & 162 & 169 & 215 & 165 & 172 & 215 & 165 & 172 & 215 \\
\hline
\end{tabular}


Reexamining The Determinants Of Fiscal Decentralization: What Is The Role Of Geography?

Table 5:Hausman Taylor panel estimation with infrastructure time variant interaction

\begin{tabular}{|c|c|c|c|c|c|c|c|c|c|c|c|c|}
\hline & \multicolumn{5}{|c|}{ Subnational Expenditure/GDP } & \multicolumn{7}{|c|}{ Subnational Revenue/GDP } \\
\hline & (1) & (2) & (3) & (4) & (5) & (6) & (7) & (8) & (9) & (10) & (11) & (12) \\
\hline \multirow[t]{2}{*}{ Log of GDP Per Capita } & -0.0014 & -0.0159 & $0.0556^{* * * *}$ & -0.0011 & -0.0156 & $0.056^{* * *}$ & 0.0032 & -0.0019 & $0.0581^{* * *}$ & 0.0021 & -0.0015 & $0.0583^{* * *}$ \\
\hline & $(0.0204)$ & $(0.0191)$ & $(0.0192)$ & $(0.0203)$ & $(0.0190)$ & $(0.0191)$ & $(0.0158)$ & $(0.0135)$ & $(0.0194)$ & $(0.0158)$ & $(0.0135)$ & $(0.0193)$ \\
\hline \multirow[t]{2}{*}{ Infant mortality } & $-0.0011^{* *}$ & $-0.0012^{* * *}$ & -0.0001 & $-0.0011^{* *}$ & $-0.0012^{* * *}$ & -0.0001 & $-0.0008^{* *}$ & $-0.0009 * * *$ & 0.0003 & $-0.0008^{* *}$ & $-0.0009 * * *$ & 0.0003 \\
\hline & $(0.0005)$ & $(0.0005)$ & $(0.0004)$ & $(0.0005)$ & $(0.0005)$ & $(0.0004)$ & $(0.0004)$ & $(0.0003)$ & $(0.0004)$ & $(0.0004)$ & $(0.0003)$ & $(0.0004)$ \\
\hline \multirow[t]{2}{*}{ Political Right } & 0.0001 & -0.0001 & $-0.0138^{* * *}$ & 0.0001 & -0.0001 & $-0.0139 * * *$ & 0.0008 & 0.0011 & $-0.0108^{* * *}$ & 0.0007 & 0.0011 & $-0.0109 * * *$ \\
\hline & $(0.0032)$ & $(0.0030)$ & $(0.0033)$ & $(0.0032)$ & $(0.0030)$ & $(0.0033)$ & $(0.0023)$ & $(0.0020)$ & $(0.0033)$ & $(0.0023)$ & $(0.0020)$ & $(0.0033)$ \\
\hline \multirow[t]{2}{*}{ Ethno- linguistic Fractionalization } & -0.0944 & -0.0127 & -0.0637 & -0.1006 & -0.0262 & -0.08 & -0.0644 & 0.0147 & $-0.0158^{*}$ & -0.0721 & 0.0106 & $-0.0324 *$ \\
\hline & $(0.0903)$ & $(0.0954)$ & $(0.0984)$ & $(0.0896)$ & $(0.0937)$ & $(0.0968)$ & $(0.0841)$ & $(0.0894)$ & $(0.0090)$ & $(0.0846)$ & $(0.0883)$ & $(0.0182)$ \\
\hline \multirow[t]{2}{*}{ Log Distance to Ports } & $-0.0457 *$ & $-0.0508^{*}$ & $-0.0711^{* *}$ & -0.0405 & $-0.0481 *$ & $-0.0646^{*}$ & $-0.0495^{* *}$ & -0.0333 & $-0.0679 *$ & $-0.0471 *$ & -0.0328 & $-0.0646^{*}$ \\
\hline & $(0.0267)$ & $(0.0264)$ & $(0.0351)$ & $(0.0270)$ & $(0.0260)$ & $(0.0342)$ & $(0.0245)$ & $(0.0246)$ & $(0.0351)$ & $(0.0250)$ & $(0.0242)$ & $(0.0344)$ \\
\hline \multirow[t]{2}{*}{ Log Area } & $0.0558^{* * *}$ & $0.0538^{* * *}$ & $0.0459 * * *$ & $0.029 * * *$ & $0.0296^{* * *}$ & $0.0295^{* * *}$ & $0.0498^{* * *}$ & $0.0533^{* * *}$ & $0.0353^{*}$ & $0.0314^{* * *}$ & $0.0346^{* * *}$ & $0.0238^{* *}$ \\
\hline & $(0.0116)$ & $(0.0121)$ & $(0.0183)$ & $(0.0072)$ & $(0.0080)$ & $(0.0105)$ & $(0.0108)$ & (0.0116) & $(0.0182)$ & $(0.0077)$ & $(0.0087)$ & $(0.0106)$ \\
\hline \multirow[t]{2}{*}{ Corruption Index } & 0.0035 & 0.0018 & 0.0019 & $0.0034^{*}$ & 0.0017 & $0.002^{*}$ & -0.0023 & 0.0001 & -0.0024 & -0.0023 & 0.0001 & -0.0024 \\
\hline & $(0.0052)$ & $(0.0049)$ & $(0.0054)$ & $(0.0020)$ & $(0.0049)$ & $(0.0010)$ & $(0.0038)$ & $(0.0033)$ & $(0.0055)$ & $(0.0038)$ & $(0.0033)$ & $(0.0055)$ \\
\hline \multirow[t]{2}{*}{ Geographical Fragmentation Index (GFI) } & $0.0198^{* * *}$ & $0.0172^{* * *}$ & $0.0137^{* *}$ & & & & $0.0128^{* * *}$ & $0.0124 * * *$ & $0.01 *$ & & & \\
\hline & $(0.0041)$ & $(0.0043)$ & $(0.0060)$ & & & & $(0.0040)$ & $(0.0041)$ & $(0.0060)$ & & & \\
\hline \multirow[t]{2}{*}{$\%$ of paved roads $*$ GFI } & 0.000001 & & & & & & 0.000001 & & & & & \\
\hline & $(0.0000)$ & & & & & & $(0.0000)$ & & & & & \\
\hline \multirow[t]{2}{*}{$\log ($ Roads km $) *$ GFI } & & 0.0002 & & & & & & 0.0007 & & & & \\
\hline & & $(0.0008)$ & & & & & & $(0.0006)$ & & & & \\
\hline \multirow[t]{2}{*}{ Log(length of track rails $) *$ GFI } & & & -0.0223 & & & & & & -0.0242 & & & \\
\hline & & & $(0.0311)$ & & & & & & $(0.0312)$ & & & \\
\hline \multirow[t]{2}{*}{ GFI *Area } & & & & $0.0008^{* * *}$ & $0.0007^{* * *}$ & $0.0007 * * *$ & & & & $0.0006^{* * *}$ & $0.0005^{* * *}$ & $0.0005^{* * *}$ \\
\hline & & & & $(0.0002)$ & $(0.0002)$ & $(0.0002)$ & & & & $(0.0002)$ & $(0.0002)$ & $(0.0002)$ \\
\hline \multirow[t]{2}{*}{$\%$ of paved roads $* \mathrm{GFI} *$ Area } & & & & 0.000001 & & & & & & 0.000001 & & \\
\hline & & & & $(0.0000)$ & & & & & & $(0.0000)$ & & \\
\hline \multirow[t]{2}{*}{$\log ($ Roads km $) *$ GFI $*$ Area } & & & & & $0.0001 *$ & & & & & & 0.000001 & \\
\hline & & & & & $(0.0001)$ & & & & & & $(0.0000)$ & \\
\hline \multirow[t]{2}{*}{$\log ($ length of track rails $) * \mathrm{GFI} *$ Area } & & & & & & -0.0016 & & & & & & -0.0018 \\
\hline & & & & & & $(0.0025)$ & & & & & & $(0.0025)$ \\
\hline \multirow[t]{2}{*}{ Constant } & -0.1032 & 0.1193 & -0.1957 & 0.1813 & 0.3895 & -0.0711 & 0.1132 & 0.054 & -0.1417 & 0.3089 & 0.2677 & -0.0491 \\
\hline & $(0.3357)$ & $(0.3108)$ & $(0.4718)$ & $(0.2990)$ & $(0.2819)$ & $(0.3747)$ & $(0.2941)$ & $(0.2671)$ & $(0.4718)$ & $(0.2602)$ & $(0.2390)$ & $(0.3781)$ \\
\hline N. of cases & 165 & 172 & 215 & 165 & 172 & 215 & 162 & 169 & 215 & 162 & 169 & 215 \\
\hline
\end{tabular}


Table 6:Robustness OLS estimations

\begin{tabular}{|c|c|c|c|c|c|c|c|c|}
\hline & \multicolumn{4}{|c|}{ Subnational Expernditures/ GDP } & \multicolumn{4}{|c|}{ Subnational Revenues / GDP } \\
\hline & (1) & (2) & (3) & (4) & (5) & (6) & (7) & (8) \\
\hline \multicolumn{9}{|l|}{ Log of GDP Per } \\
\hline \multirow[t]{2}{*}{ Capita } & $0.0773 * *$ & $0.0992^{*}$ & $0.0694 * *$ & 0.078 & $0.0465^{* *}$ & $0.0669 *$ & 0.0285 & 0.0468 \\
\hline & $(0.0347)$ & $(0.0562)$ & $(0.0354)$ & $(0.0504)$ & $(0.0235)$ & $(0.0346)$ & $(0.0551)$ & $(0.0521)$ \\
\hline \multirow[t]{2}{*}{ Infant mortality } & 0.0001 & 0 & -0.0001 & 0 & -0.0005 & -0.0006 & -0.0007 & -0.0005 \\
\hline & $(0.0012)$ & $(0.0011)$ & $(0.0012)$ & $(0.0012)$ & $(0.0012)$ & $(0.0012)$ & $(0.0012)$ & $(0.0012)$ \\
\hline \multirow[t]{2}{*}{ Political Right } & $-0.0198^{* *}$ & -0.0253 & $-0.019^{* *}$ & -0.0218 & $-0.0216^{*}$ & -0.0272 & $-0.023 * *$ & -0.0222 \\
\hline & $(0.0088)$ & $(0.0163)$ & $(0.0082)$ & $(0.0184)$ & $(0.0125)$ & $(0.0181)$ & $(0.0110)$ & $(0.0199)$ \\
\hline \multicolumn{9}{|l|}{ Ethno- linguistic } \\
\hline \multirow[t]{2}{*}{ Fractionalization } & 0.11 & $0.0282^{*}$ & $0.1355^{*}$ & 0.1046 & 0.1353 & 0.0593 & 0.1397 & 0.1338 \\
\hline & $(0.1102)$ & $(0.0169)$ & $(0.0711)$ & $(0.1064)$ & $(0.1070)$ & $(0.1040)$ & $(0.1023)$ & $(0.1059)$ \\
\hline \multicolumn{9}{|l|}{ Log Distance to } \\
\hline \multirow[t]{2}{*}{ Ports } & -0.031 & -0.0342 & $-0.0516^{* *}$ & -0.0278 & -0.02 & -0.0225 & $-0.0496 * * *$ & -0.0189 \\
\hline & $(0.0267)$ & $(0.0244)$ & $(0.0228)$ & $(0.0250)$ & $(0.0286)$ & $(0.0266)$ & $(0.0204)$ & $(0.0276)$ \\
\hline \multirow[t]{2}{*}{ Log Area } & $0.0395^{* *}$ & $0.0461^{* * *}$ & $0.0397 * *$ & $0.0372 * *$ & $0.0479 * *$ & $0.0544 * * *$ & $0.0542^{* * *}$ & $0.0474 * *$ \\
\hline & $(0.0179)$ & $(0.0185)$ & $(0.0181)$ & $(0.0178)$ & $(0.0214)$ & $(0.0218)$ & $(0.0213)$ & $(0.0214)$ \\
\hline \multicolumn{9}{|l|}{ Corruption } \\
\hline \multirow[t]{2}{*}{ Index } & -0.0034 & $-0.0054^{*}$ & -0.0004 & -0.0054 & -0.0141 & -0.0167 & -0.0051 & -0.0141 \\
\hline & $(0.0022)$ & $(0.0032)$ & $(0.0304)$ & $(0.0331)$ & $(0.0332)$ & $(0.0340)$ & $(0.0308)$ & $(0.0343)$ \\
\hline \multirow[t]{2}{*}{ SD Elevation } & & $0.0002^{* *}$ & & & & 0.0001 & & \\
\hline & & $(0.0001)$ & & & & $(0.0001)$ & & \\
\hline \multirow[t]{2}{*}{ Gini_Climate } & & & 0.161 & & & & 0.0706 & \\
\hline & & & $(0.1496)$ & & & & $(0.1373)$ & \\
\hline \multirow[t]{2}{*}{ Gini_Elevation } & & & & $0.1414 *$ & & & & 0.0349 \\
\hline & & & & $(0.0791)$ & & & & $(0.1602)$ \\
\hline \multirow[t]{2}{*}{ Constant } & -0.1609 & -0.2905 & 0.1291 & -0.2039 & 0.0339 & -0.0981 & 0.3042 & 0.033 \\
\hline & $(0.5156)$ & $(0.4778)$ & $(0.6314)$ & $(0.5684)$ & $(0.5334)$ & $(0.5113)$ & $(0.5507)$ & $(0.5881)$ \\
\hline N. of cases & 338 & 338 & 316 & 338 & 335 & 335 & 313 & 335 \\
\hline
\end{tabular}




\section{Table 7: Robustness Panel estimations}

\begin{tabular}{|c|c|c|c|c|c|c|c|c|}
\hline & \multicolumn{4}{|c|}{ Subnational Expenditures/ GDP } & \multicolumn{4}{|c|}{ Subnational Revenues / GDP } \\
\hline & (1) & (2) & (3) & (4) & (5) & (6) & (7) & (8) \\
\hline \multicolumn{9}{|l|}{ Log of GDP Per } \\
\hline \multirow[t]{2}{*}{ Capita } & $0.0721 * *$ & $0.0938^{* *}$ & $0.0702^{* *}$ & $0.0789 *$ & $0.0608^{*}$ & $0.0816^{*}$ & $0.0518^{*}$ & 0.063 \\
\hline & $(0.0345)$ & $(0.0409)$ & $(0.0346)$ & $(0.0453)$ & $(0.0351)$ & $(0.0481)$ & $(0.0295)$ & $(0.0498)$ \\
\hline \multirow[t]{2}{*}{ Infant mortality } & -0.0008 & -0.0009 & -0.0009 & -0.0009 & -0.001 & -0.0012 & -0.0012 & -0.0011 \\
\hline & $(0.0011)$ & $(0.0011)$ & $(0.0011)$ & $(0.0011)$ & $(0.0012)$ & $(0.0011)$ & $(0.0012)$ & $(0.0011)$ \\
\hline \multirow[t]{2}{*}{ Political Right } & -0.0213 & $-0.0244 * *$ & $-0.0205^{* *}$ & $-0.0227 *$ & -0.0217 & $-0.0254^{*}$ & -0.0225 & -0.0218 \\
\hline & $(0.0135)$ & $(0.0103)$ & $(0.0104)$ & $(0.0138)$ & $(0.0155)$ & $(0.0151)$ & $(0.0163)$ & $(0.0155)$ \\
\hline \multicolumn{9}{|l|}{ Ethno- linguistic } \\
\hline \multirow[t]{2}{*}{ Fractionalization } & 0.1498 & $0.0589 *$ & $0.1825^{* *}$ & 0.1401 & 0.1503 & 0.0625 & 0.1599 & 0.1486 \\
\hline & $(0.1286)$ & $(0.0312)$ & $(0.0913)$ & $(0.1270)$ & $(0.1216)$ & $(0.1181)$ & $(0.1213)$ & $(0.1244)$ \\
\hline \multicolumn{9}{|l|}{ Log Distance to } \\
\hline \multirow[t]{2}{*}{ Ports } & -0.0282 & -0.0333 & $-0.0484^{* *}$ & -0.0267 & -0.0165 & -0.0201 & $-0.0471 * *$ & -0.0167 \\
\hline & $(0.0270)$ & $(0.0241)$ & $(0.0240)$ & $(0.0252)$ & $(0.0287)$ & $(0.0268)$ & $(0.0219)$ & $(0.0281)$ \\
\hline \multirow[t]{2}{*}{ Log Area } & $0.0389^{*}$ & $0.0451 * *$ & $0.0364^{*}$ & $0.0362^{*}$ & $0.0538^{* *}$ & $0.0604^{* * *}$ & $0.0574 * *$ & $0.0541 * *$ \\
\hline & $(0.0201)$ & $(0.0211)$ & $(0.0200)$ & $(0.0202)$ & $(0.0245)$ & $(0.0250)$ & $(0.0243)$ & $(0.0249)$ \\
\hline \multicolumn{9}{|l|}{ Corruption } \\
\hline \multirow[t]{2}{*}{ Index } & -0.0161 & $-0.0158 *$ & -0.0137 & -0.0153 & -0.0224 & -0.0235 & -0.0173 & -0.021 \\
\hline & $(0.0304)$ & $(0.0093)$ & $(0.0093)$ & $(0.0306)$ & $(0.0302)$ & $(0.0311)$ & $(0.0288)$ & $(0.0305)$ \\
\hline \multirow[t]{2}{*}{ SD Elevation } & & $0.0002^{* *}$ & & & & $0.0002 * *$ & & \\
\hline & & $(0.0001)$ & & & & $(0.0001)$ & & \\
\hline \multirow[t]{2}{*}{ Gini_Climate } & & & 0.2361 & & & & 0.0974 & \\
\hline & & & $(0.1687)$ & & & & $(0.1519)$ & \\
\hline \multirow[t]{2}{*}{ Gini_Elevation } & & & & $0.1554^{* *}$ & & & & -0.0148 \\
\hline & & & & $(0.0717)$ & & & & $(0.1661)$ \\
\hline \multirow[t]{2}{*}{ Constant } & -0.0895 & -0.2001 & -0.0133 & -0.1566 & -0.0651 & -0.2016 & 0.2104 & -0.0398 \\
\hline & $(0.4079)$ & $(0.3959)$ & $(0.4522)$ & $(0.4719)$ & $(0.4418)$ & $(0.4289)$ & $(0.4523)$ & $(0.5044)$ \\
\hline N. of cases & 338 & 338 & 316 & 338 & 335 & 335 & 313 & 335 \\
\hline
\end{tabular}




\section{Table 8:Robustness Hausman-Taylor estimations}

\begin{tabular}{|c|c|c|c|c|c|c|c|c|}
\hline & \multicolumn{4}{|c|}{ Subnational Expenditures/ GDP } & \multicolumn{4}{|c|}{ Subnational Revenues / GDP } \\
\hline & (1) & (2) & (3) & (4) & (5) & (6) & (7) & (8) \\
\hline \multicolumn{9}{|l|}{ Log of GDP Per } \\
\hline \multirow[t]{2}{*}{ Capita } & $0.0958^{* *}$ & $0.1031 *$ & $0.1057^{*}$ & 0.1026 & $0.1118^{*}$ & $0.1204 *$ & 0.1215 & 0.118 \\
\hline & $(0.0468)$ & $(0.0567)$ & $(0.0572)$ & $(0.0677)$ & $(0.0673)$ & $(0.0672)$ & $(0.0767)$ & $(0.0727)$ \\
\hline \multirow[t]{2}{*}{ Infant mortality } & -0.0005 & -0.0006 & -0.0005 & -0.0006 & -0.0003 & -0.0005 & -0.0002 & -0.0003 \\
\hline & $(0.0014)$ & $(0.0014)$ & $(0.0014)$ & $(0.0014)$ & $(0.0015)$ & $(0.0014)$ & $(0.0015)$ & $(0.0015)$ \\
\hline \multirow[t]{2}{*}{ Political Right } & $-0.0215^{* *}$ & $-0.025^{*}$ & $-0.0211^{* *}$ & -0.0226 & -0.02 & $-0.0246^{* *}$ & $-0.0203 *$ & -0.0199 \\
\hline & $(0.0105)$ & $(0.0149)$ & $(0.0106)$ & $(0.0152)$ & $(0.0162)$ & $(0.0110)$ & $(0.0107)$ & $(0.0163)$ \\
\hline \multicolumn{9}{|l|}{ Ethno- linguistic } \\
\hline \multirow[t]{2}{*}{ Fractionalization } & 0.0973 & 0.0148 & 0.1294 & 0.0902 & 0.115 & 0.0313 & 0.1277 & 0.1148 \\
\hline & $(0.1381)$ & $(0.0214)$ & $(0.0914)$ & $(0.1377)$ & $(0.1365)$ & $(0.1349)$ & $(0.1403)$ & $(0.1367)$ \\
\hline \multicolumn{9}{|l|}{ Log Distance to } \\
\hline \multirow[t]{2}{*}{ Ports } & -0.0524 & -0.0523 & $-0.0797 *$ & -0.0502 & -0.0319 & -0.0347 & -0.0637 & -0.0308 \\
\hline & $(0.0406)$ & $(0.0381)$ & $(0.0443)$ & $(0.0408)$ & $(0.0393)$ & $(0.0372)$ & $(0.0419)$ & $(0.0395)$ \\
\hline \multirow[t]{2}{*}{ Log Area } & $0.0362 * * *$ & $0.0434 * * *$ & $0.0366^{* * *}$ & $0.0341 * * *$ & $0.0497^{* * *}$ & $0.0565^{* * *}$ & $0.0559 * * *$ & $0.0496^{* * *}$ \\
\hline & $(0.0108)$ & $(0.0106)$ & $(0.0119)$ & $(0.0112)$ & $(0.0117)$ & $(0.0115)$ & $(0.0132)$ & $(0.0124)$ \\
\hline \multicolumn{9}{|l|}{ Corruption } \\
\hline \multirow[t]{2}{*}{ Index } & -0.0213 & $-0.0199 * *$ & $-0.0208^{* *}$ & -0.021 & -0.0275 & -0.0286 & -0.0238 & -0.0268 \\
\hline & $(0.0235)$ & $(0.0092)$ & $(0.0093)$ & $(0.0235)$ & $(0.0249)$ & $(0.0243)$ & $(0.0266)$ & $(0.0249)$ \\
\hline \multirow[t]{2}{*}{ SD Elevation } & & $0.0002^{* *}$ & & & & $0.0002 * *$ & & \\
\hline & & $(0.0001)$ & & & & $(0.0001)$ & & \\
\hline \multirow[t]{2}{*}{ Gini_Climate } & & & 0.1121 & & & & 0.0052 & \\
\hline & & & $(0.2108)$ & & & & $(0.2093)$ & \\
\hline \multirow[t]{2}{*}{ Gini_Elevation } & & & & $0.1336^{*}$ & & & & 0.0056 \\
\hline & & & & $(0.0725)$ & & & & $(0.2510)$ \\
\hline \multirow[t]{2}{*}{ Constant } & 0.0227 & -0.0115 & 0.1225 & -0.0541 & -0.3299 & -0.354 & -0.192 & -0.3782 \\
\hline & $(0.7703)$ & $(0.7530)$ & $(0.8270)$ & $(0.7936)$ & $(0.8037)$ & $(0.7866)$ & $(0.8533)$ & $(0.8190)$ \\
\hline N. of cases & 338 & 338 & 316 & 338 & 335 & 335 & 313 & 335 \\
\hline
\end{tabular}

